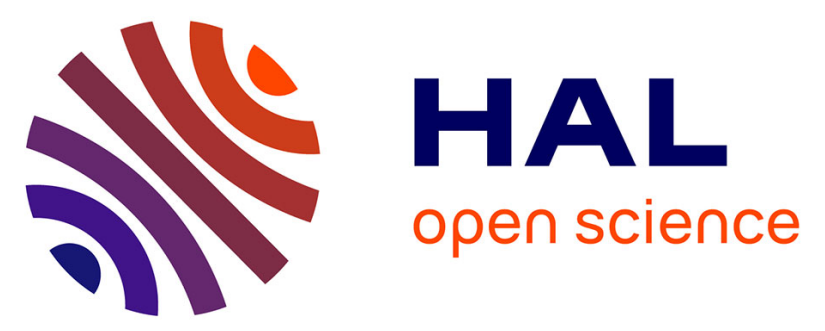

\title{
Use of fluorescence spectroscopy and voltammetry for the analysis of metal- organic matter interactions in the New Caledonia lagoon
}

Patricia Merdy, Aurélie Bonnefoy, Céline Martias, Cédric Garnier, Sandrine Huclier

\section{To cite this version:}

Patricia Merdy, Aurélie Bonnefoy, Céline Martias, Cédric Garnier, Sandrine Huclier. Use of fluorescence spectroscopy and voltammetry for the analysis of metal- organic matter interactions in the New Caledonia lagoon. International Journal of Environmental Analytical Chemistry, 2011, 92 (7), pp.868-893. 10.1080/03067319.2010.520317 . hal-01096848

\section{HAL Id: hal-01096848 \\ https://hal-univ-tln.archives-ouvertes.fr/hal-01096848}

Submitted on 5 Jan 2015

HAL is a multi-disciplinary open access archive for the deposit and dissemination of scientific research documents, whether they are published or not. The documents may come from teaching and research institutions in France or abroad, or from public or private research centers.
L'archive ouverte pluridisciplinaire HAL, est destinée au dépôt et à la diffusion de documents scientifiques de niveau recherche, publiés ou non, émanant des établissements d'enseignement et de recherche français ou étrangers, des laboratoires publics ou privés. 
This article was downloaded by: [McGill University Library]

On: 20 December 2011, At: 13:29

Publisher: Taylor \& Francis

Informa Ltd Registered in England and Wales Registered Number: 1072954 Registered

office: Mortimer House, 37-41 Mortimer Street, London W1T 3J H, UK

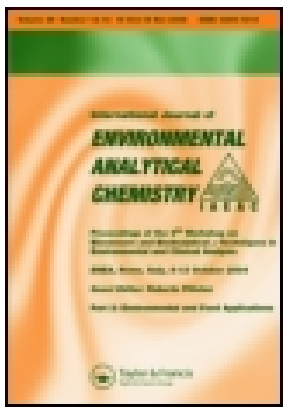

\section{International J ournal of Environmental Analytical Chemistry}

Publication details, including instructions for authors and subscription information:

http:// www.tandfonline.com/loi/geac20

\section{Use of fluorescence spectroscopy and voltammetry for the analysis of metal- organic matter interactions in the New Caledonia lagoon}

Patricia Merdy ${ }^{a}$, Aurélie Bonnefoy ${ }^{a}$, Céline Martias ${ }^{a}$, Cédric Garnier ${ }^{a} \&$ Sandrine Huclier ${ }^{b}$

a University of Toulon, Research Group PROTEE (Processus de Transferts et d'Echanges dans I'Environnement), BP 20132-83957 La Garde Cedex, France

${ }^{b}$ SUBATECH Ecole des Mines de Nantes, 14 rue Alfred Kastler BP 20722-44307 Nantes Cedex 3, France

Available online: 11 Nov 2011

To cite this article: Patricia Merdy, Aurélie Bonnefoy, Céline Martias, Cédric Garnier \& Sandrine Huclier (2011): Use of fluorescence spectroscopy and voltammetry for the analysis of metal-organic matter interactions in the New Caledonia Iagoon, International J ournal of Environmental Analytical Chemistry, DOI: 10.1080/ 03067319.2010.520317

To link to this article: http:// dx.doi.org/ 10.1080/ 03067319.2010.520317

\section{iFirst}

\section{PLEASE SCROLL DOWN FOR ARTICLE}

Full terms and conditions of use: http://www.tandfonline.com/page/terms-andconditions

This article may be used for research, teaching, and private study purposes. Any substantial or systematic reproduction, redistribution, reselling, Ioan, sub-licensing, systematic supply, or distribution in any form to anyone is expressly forbidden.

The publisher does not give any warranty express or implied or make any representation that the contents will be complete or accurate or up to date. The accuracy of any instructions, formulae, and drug doses should be independently verified with primary 
sources. The publisher shall not be liable for any loss, actions, claims, proceedings, demand, or costs or damages whatsoever or howsoever caused arising directly or indirectly in connection with or arising out of the use of this material. 


\title{
Use of fluorescence spectroscopy and voltammetry for the analysis of metal-organic matter interactions in the New Caledonia lagoon
}

\author{
Patricia Merdy $^{\mathrm{a} *}$, Aurélie Bonnefoy ${ }^{\mathrm{a}}$, Céline Martias ${ }^{\mathrm{a}}$, \\ Cédric Garnier ${ }^{\mathrm{a}}$ and Sandrine Huclier ${ }^{\mathrm{b}}$ \\ ${ }^{a}$ University of Toulon, Research Group PROTEE (Processus de Transferts et d'Echanges \\ dans l'Environnement), BP 20132-83957 La Garde Cedex, France; ${ }^{b}$ SUBATECH Ecole \\ des Mines de Nantes, 14 rue Alfred Kastler BP 20722-44307 Nantes Cedex 3, France
}

(Received 29 January 2010; final version received 30 August 2010)

\begin{abstract}
Fluorescence, polarographic and potentiometric analysis of sea water from the New Caledonia lagoon (located south of Noumea) allowed the determination of the specific properties of the dissolved and particulate phases of organic matter (OM)-metal complexes according to various regions of the lagoon. In particular, OM complexes with $\mathrm{Ni}, \mathrm{Zn}, \mathrm{Pb}, \mathrm{Cu}, \mathrm{Cd}$ were chosen in this study due to the sensitivity of these complexes to affect biocenosis of the nearby enclosed coral reef as well as their availability to enter the coast from erosion (terrigenous $\mathrm{OM}$ ) or human activities from nickel extraction or pollution from waste sites (anthopogenic OM) that exist throughout New Caledonia. Combined with geochemical modelling, the OM-metal complexes analysis allowed the determination of their conditional stability constants which in turn helped in predicting the fate of the metal pollution in the lagoon. For the first time, fluorescence, polarographic and potentiometric techniques combined with geochemical models that employed discrete $\mathrm{pKa}$ distribution on $\mathrm{OM}$ enabled the determination of the origin of the $\mathrm{OM}$, as either natural or anthopogenic.
\end{abstract}

Keywords: potentially toxic metals; organic matter; voltammetry; fluorescence; quenching, modelling

\section{Introduction}

Anthropogenic pollutions such as industrial wastes and sewage sludge often affect coastal areas. These anthropogenic inputs can be associated with inorganic or organic pollutants [1], which are responsible for their transport and spread. In New Caledonia Island, nickel extraction mining activities and the urban area of Noumea city represent environmental issues in term of pollution from land to the lagoon [2]. As a consequence of mining extraction, erosion leading to terrigenous inputs is accelerated, especially as a direct consequence of deforestation. The Southern Lagoon near Noumea city is affected by these inputs at different levels. Sea plants, coral, fishes and sediments are accumulating

*Corresponding author. Email: merdy@univ-tln.fr 
pollutants, leading to serious disturbances of the ecosystem. Mining activity promotes sedimentation and leads to transition metals inputs [3-4]. Impacts of this pollution on human health, on living organisms and the whole ecosystem have been intensively studied since 1999 within the framework of the French National Programme on Coastal Environment (PNEC) [5-9].

Furthermore, Ouillon [10] has developed, under the PNEC framework, a numerical code to simulate the transport of suspended sediments in the lagoon. This study could help understanding the effects of pollutants in the lagoon. Among the pollutants that we chose to study, cadmium and lead are of considerable interest in view of their toxicity and accumulation in the environment. They have been the subject of numerous studies in terms of their toxicity on marine organisms and plants. Some effects of lead on populations and ecosystems were reviewed by Gnassia-Barelli [11]. The author showed that in controlled ecosystems, tetraethyl lead can persist in sediments at a depth of $5 \mathrm{~m}$ and exert a toxic effect on the fauna. According to the author, lead can be rapidly taken up by marine organisms through controlled diffusion processes and may affect specific biochemical functions. Moreover, cadmium is a serious issue associated with industrial processes. It is one of six substances banned by the European Union's Restriction of Hazardous Substances (RoHS) directive [12] that consequently have to be tightly controlled in the environment.

In freshwaters, cadmium is closely associated with colloidal and particulate matter and soluble specation is restricted to the free $\mathrm{Cd}^{2+}$ ions together with $\mathrm{CdCl}_{2}$ and $\mathrm{CdSO}_{4}$. In the sea $66 \%$ of cadmium is present as free $\mathrm{Cd}^{2+}$ together with $\mathrm{CdCO}_{3}(26 \%)$ and $\mathrm{Cd}(\mathrm{OH})_{2}$ $(5 \%), \mathrm{CdSO}_{4}(1 \%)$ and $\mathrm{CdCl}_{2}(1 \%)$ [13]. Within continental aquatic freshwater, this xenobiotic is considered as one of the most toxic metals and represents a risk for aquatic organisms. The $\mathrm{Cd}$ toxicity is mainly attributed to the disruption of some metalloenzymes, $\mathrm{Cd}^{2+}$ replacing essential metal nutrients such as zinc, copper and calcium [14]. Risk assessment, in terms of transfer factors or levels of bio-accumulation, must take into account the speciation of this element. Copper compounds have been widely used in industrial processes and agriculture and as a result can be found in toxic concentration in the environment, even though at low concentration it is an essential nutrient for the growth of plants and animals [15]. Zinc is a common pollutant, widely spread in the aquatic environment. It originates mainly from weathering of minerals and soils, atmospheric deposition, industrial and domestic effluents [16-17]. The high aquatic toxicity of $\mathrm{Zn}$, and especially towards fishes, has been shown [18-20]. Detrimental effects of $\mathrm{Zn}$ on the environment are enhanced as a result of lowered $\mathrm{pH}$ [21]. Finally, Ni contamination threat for marine ecosystem has been reported [2] and its high concentrations can originate from industrial activities such as mining.

$\mathrm{OM}$ controls the mobility and bioavailability of potentially toxic metal ions through complexation processes taking place in dissolved or solid phases. It is then crucial to understand the interactions between $\mathrm{OM}$ and metal ions according to its origin in term of risk assessment. Among the techniques that can be used to determine the origin of the OM, fluorescence can be used as an indicator of water quality and can establish by the specific fingerprint (specific emission and excitation wavelengths) of the compounds the autochthonous or allochtonous origin of organic matter. It is possible to evaluate the extent of the anthropogenic inputs of dissolved $\mathrm{OM}$ in natural waters, since the dissolved terrigenous $\mathrm{OM}$ differs in nature from the marine $\mathrm{OM}$. Marine $\mathrm{OM}$ is mainly the result of degradation or excretions of bacteria and phytoplankton. The proportion brought in OM by sea plants and sea animals is very low. On the contrary, the terrigenous OM includes an 
important fraction of plants which contain polymers difficult to degrade such as lignin or cellulose [22]. These differences in composition induce differences in their fluorescence spectral signatures.

This paper is an investigation of the interactions between heavy metal ions and OM (colloidal and dissolved) in a view of predicting the mobility and the fate of $\mathrm{Ni}, \mathrm{Zn}, \mathrm{Pb}, \mathrm{Cu}$ and $\mathrm{Cd}$ in the lagoon of New Caledonia. The originality of this study lies into the combination of modellings obtained from fluorescence and electroanalytical techniques to allow OM discrimination according to its nature, origin and its capacity of complexing metal ions.

The first part of the study aims at analysing the various samples. Metal concentrations $(\mathrm{Ni}, \mathrm{Zn}, \mathrm{Pb}, \mathrm{Cu}$ and $\mathrm{Cd}$ ) were measured in the lagoon at specific locations along the shore and along transects to monitor the dilution effect from the coast. These concentrations were measured in both dissolved and solid phases to determine the metal speciation. Correlations with carbon content were evaluated to specify the mobility process of the metal ions along with OM. Anthropogenic, terrigenous and marine inputs were quantified.

The second part of the study discusses the results of the modelling obtained from fluorescence, voltammetric and potentiometric data. For these purpose, field data and modellings were combined to predict the biogeochemical fate of heavy metals in the lagoon. Voltammetry and potentiometry allowed, after modelling, the determination of acido-basic properties of OM, conditional stability constants of OM-metal complexes and complexation capacity of OM towards the metal ions considered. The complexing properties of $\mathrm{OM}$ are difficult to model because of their structural complexity, heterogeneity, diversity and polydispersity. However, the interest of modelling is to understand and predict the complexing behaviour of the $\mathrm{OM}$ in regard to metal pollutants in natural environment. It allows the prediction of transport and fate of contaminants in the various compartments of the environment. Various analytical techniques can be used for such prediction, such as, in our case, differential pulse anodic stripping voltammetry (DPASV), fluorescence quenching and potentiometry. They present the advantage of being non-destructive and each technique takes advantage of a specific property of OM, allowing one to obtain complementary information. The interests of comparing these various techniques in the modelling results are the fact that we do not observe the same OM property: the fluorescence data are related to the ability of metal to quench the fluorescence signal of OM upon complexation, while the potentiometric titrations are informative in the acido-basic properties of the OM. Finally, the DPASV technique observes the behaviour of the labile metal ions being complexed to the OM. In this study, the modelling of the polarographic titrations with lead in interactions with the samples was performed while the fluorescence quenching modelling was related to copper-OM complexes.

\section{Experimental}

\subsection{Study area}

New Caledonia lagoon in bays located near Noumea city was chosen as study area to quantify and characterise land-based sources of pollution that could impact the coral reefs. Seven main sampling sites were chosen according to anthropogenic, terrigenous or oceanic influences (Figure 1). A reference sample was collected in the middle of the lagoon $10 \mathrm{~km}$ 

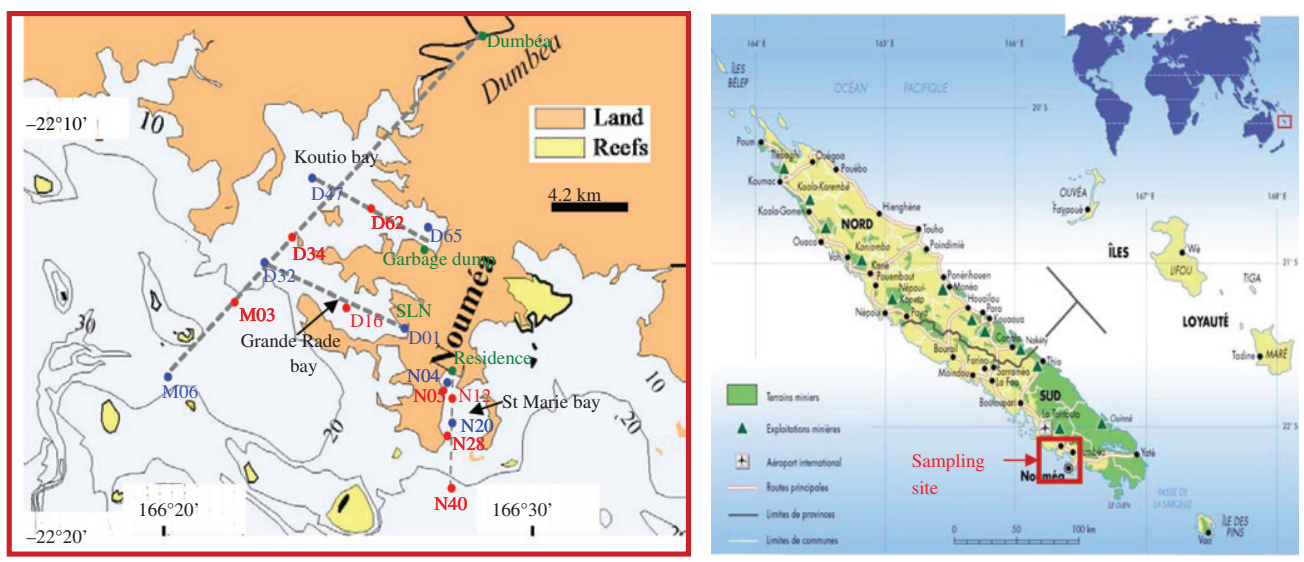

Figure 1. New Caledonia sampling sites.

from the shore (M06). Grande Rade Bay is close to the mining Company 'Societe Le Nickel' (SLN) and clearly receives anthropogenic inputs [23]. For this reason, two samples were collected: one close to the SLN Company (D01) and a second one (D32) located $7 \mathrm{~km}$ farther to evaluate the distribution of pollutants in Grande Rade Bay. Furthermore, a garbage dump station (D65) of domestic wastes was chosen with a dilution sampling site located $6 \mathrm{~km}$ farther (D47) to estimate the impact of the pollution from this dump in Koutio Bay. A third group of samples was collected to determine the urban inputs in St Marie Bay: N04 close to the shore and N20 collected $1.5 \mathrm{~km}$ farther. An exhaustive study was achieved on these seven main sampling sites (M06, D47, N04, N20, D65, D01 and D32). Furthermore, eight additional samples were collected to precise the carbon and metal evolution from the coast to the lagoon (D62, D34, M03, N05, N12, N40, N28 and D16) along transects (Figure 1). In particular, the D16 sample site is located near by the canal receiving the waste waters of the SLN factory. Finally, three more samples were collected 2 metres from the coast to evaluate the direct input of metal from the garbage dump, the Dumbea River and the St Marie Bay, named 'garbage dump', 'Dumbea' and 'residence' (Figure 1) respectively.

\subsection{Water sampling and preservation of samples}

All chemicals were trace analysis grade and were used without any further purification. Distilled and deionised water used for the preparation of the solutions had a resistivity of at least $18 \mathrm{M} \Omega \mathrm{cm}$. Metal reagents (Fisher, analytical grade) were used in the reference solutions for all the experiments as nitrate solutions.

All samples $(100 \mathrm{~L})$ were collected in the lagoon at the subsurface $(1 \mathrm{~m}$ deep). They were treated differently depending on the analysis: for carbon analysis, $2 \mathrm{~L}$ of samples were filtered on glass fibre filter (Whatman $\mathrm{GF} / \mathrm{F}, 0.7 \mu \mathrm{m}$ porosity) membranes and were preserved by azidification $\left(\mathrm{NaN}_{3} 1 \mathrm{~mol} \mathrm{~L}^{-1}, 500 \mu \mathrm{LL}^{-1}\right.$ of sample) to avoid microorganism development. For metal measurements, the samples were filtered through nitrocellulose filter membranes $\left(0.45 \mu \mathrm{m}\right.$ porosity) and preserved by acidification $\left(\mathrm{HNO}_{3}\right.$ $70 \%, 500 \mu \mathrm{L} \mathrm{L}^{-1}$ of sample). Before any sample filtration, $100 \mathrm{~mL}$ of $\mathrm{HNO}_{3} 10 \%$ were 


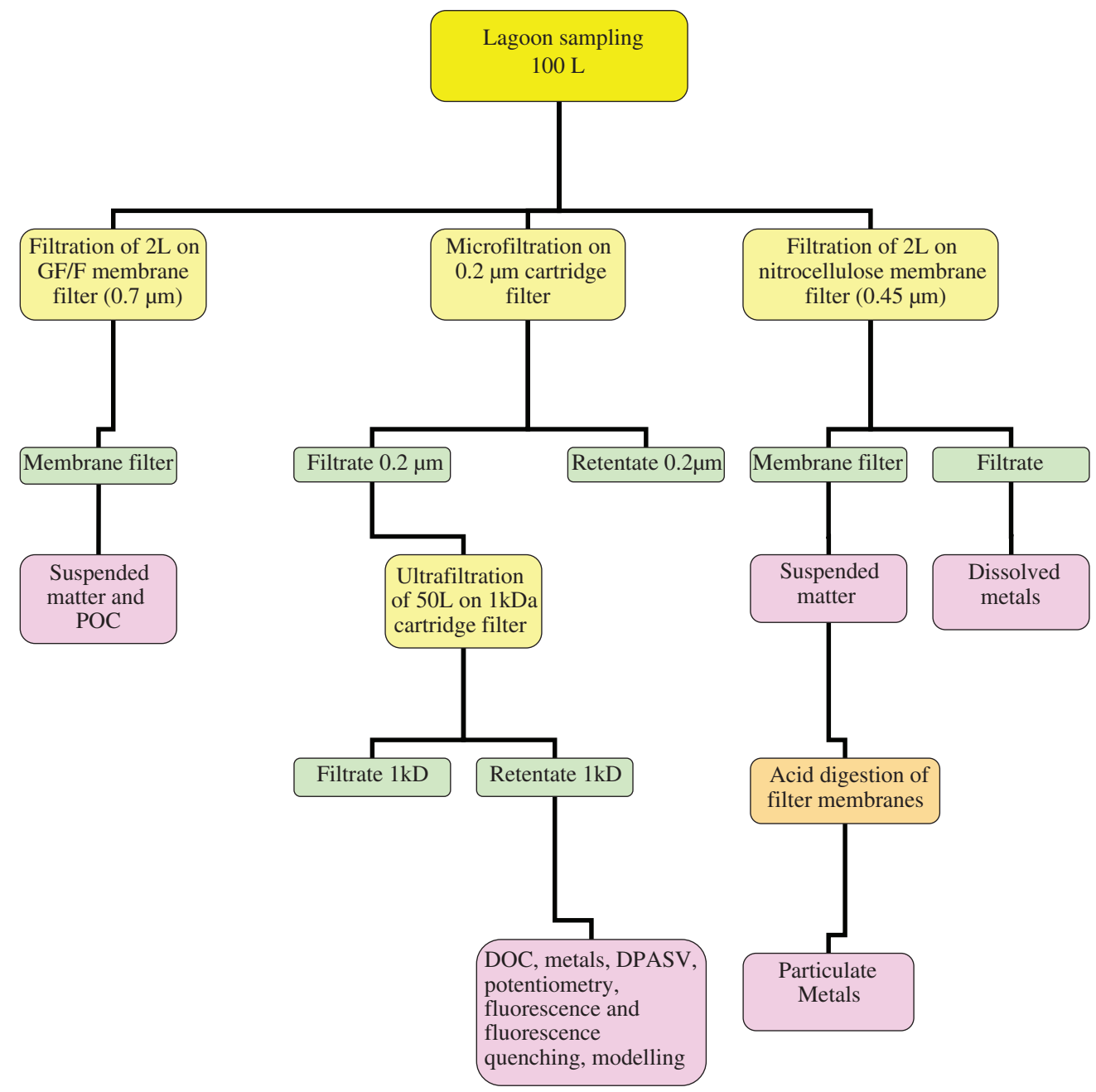

Figure 2. Schematic sampling procedure used and chemical analyses.

passed through the nitrocellulose membranes to eliminate metal traces and the $\mathrm{GF} / \mathrm{F}$ filters were pre-combusted at $450^{\circ} \mathrm{C}$ (Whatman, pore size $0.7 \mu \mathrm{m}$ ) for 4 hours to destroy any organic carbon traces. A schematic summary of the sampling procedure and the chemical analyses performed on the various samples are shown in Figure 2.

\subsection{Ultrafiltration}

After frontal filtration, the crude samples were concentrated from about $96 \mathrm{~L}$ to $2 \mathrm{~L}$ by ultrafiltration. A cell assembled with ultrafiltration membranes of molecular mass cut-off of $0.2 \mu \mathrm{m}$ and $1 \mathrm{kDa}$ at operation pressure around 1 bar was used. Retentates and filtrates from all ultrafiltration runs were collected for analysis (Figure 2). Retentates were collected for their high concentration in carbon, for fluorescence and 
electrochemical analyses. Colloidal fractions were considered as being composed by molecules ranging in size from $1 \mu \mathrm{m}$ to $1 \mathrm{~nm}(1 \mathrm{kDa})$ while molecules in the dissolved fraction are usually considered as being under $1 \mathrm{~nm}$ size $(<1 \mathrm{kDa})$ [24-25].

The apparatus consisted of a QuattroFlow centrifugal pump with two Centramate cartridge filters set up in parallel. Between two ultrafiltrations of crude samples, the $0.22 \mu \mathrm{m}$ cartridge filters were washed successively with: (1) distilled water, (2) $\mathrm{NaOH}$ $0.2 \mathrm{~mol} \mathrm{~L}^{-1}$, (3) purified water, (4) $\mathrm{HNO}_{3} 1 \%$. The $1 \mathrm{kDa}$ cartridge filters were washed successively with ethanol $25 \%, \mathrm{NaOH} 0.2 \mathrm{~mol} \mathrm{~L}{ }^{-1}$ and $\mathrm{HNO}_{3} 1 \%$. Distilled water was passed through the cartridge in between each washing solution. The eventual release of metals from the ultrafiltration cartridges was tested by measuring the metal content in the first and last sample ultrafiltrated (both M06). No difference in carbon or metal concentration was found between these two samples. Furthermore, the cautious cleaning procedure set up in between each sample was applied to prevent any contamination.

\subsection{Carbon analysis and suspended matter}

Total organic carbon (TOC) was determined using a Shimadzu TOC-5000A analyser, equipped with a solid-module SSM-5000A, and a module ASI-5000A for dissolved carbon. The measurement was based on $\mathrm{CO}_{2}$ quantification by non-dispersive infrared analysis after high-temperature catalytic combustion $\left(680^{\circ} \mathrm{C}\right)$. The calibration curve was achieved between 5 and $100 \mathrm{mg} \mathrm{L}^{-1}$ from a potassium hydrogenophtalate solution. Every 10 samples, a $10 \mathrm{mg} \mathrm{L}^{-1}$ solution was measured to check the reproducibility of the signal and a distilled water sample was also included regularly to wash the system and check the blank signal. Particulate organic carbon (POC) analyses were applied to the solid samples. A calibration curve was achieved up to $400 \mathrm{mg} \mathrm{g}^{-1}$ from a glucose standard solution placed on glass fibre wool in a ceramic boat. The combustion took place at $900^{\circ} \mathrm{C}$ and the detection of $\mathrm{CO}_{2}$ was made by IR. The mean values and standard deviation values were obtained on three to five measurements of pre-weighed pieces of filter. Quantification limits for this analytical method were evaluated to $0.1 \mu \mathrm{g} \mathrm{L}^{-1}$ for TOC analyses and $1 \mathrm{mg}$ for POC analyses. They were evaluated based on the minimum level at which a known concentration (reference standard: potassium hydrogenophtalate, Prolabo) was reliably detected and quantified.

Suspended matter (SM) values were determined as the weight of material retained on a Whatman GF/F membrane per volume unit after air-drying the filter for $2 \mathrm{~h}$ at $120^{\circ} \mathrm{C}$.

\subsection{Metal concentration}

Microwave-assisted sample digestions of membrane filters were achieved by means of a microwave oven (Anton Paar, Multiwave 3000) and were used in order to measure metals on the particulate fractions.

The filter membranes were cut into pieces and weighed precisely (in a range between 30 to $40 \mathrm{mg}$ ). Each piece was treated with diluted aqua regia (mixture of $\mathrm{HNO}_{3} 8 \mathrm{~mol} \mathrm{~L}^{-1}$ and $\mathrm{HCl} 8 \mathrm{~mol} \mathrm{~L}^{-1}$ solutions in a ratio $\left.1 / 3: 2 / 3 \mathrm{~V} / \mathrm{V}\right)$. The liner was placed in the digestion vessel body and the pressure controller cap assembly was tighten on the vessel body. The mineralisation programme was then set up as follows: (1) power increases up to $1000 \mathrm{~W}$ within $10 \mathrm{~min}$, (2) stabilisation at $1000 \mathrm{~W}$ for $5 \mathrm{~min}$, (3) cooling phase during $20 \mathrm{~min}$. 
A blank sample consisting of the aqua regia solution followed the same procedure to check any metal contamination. The metal content of the blank was subtracted from the ones of the samples. The samples were then collected and analysed for their metal content by ICP-MS.

The metal concentrations analysis in solid and dissolved phases was performed using an inductively coupled plasma coupled with a mass spectrometer (ICP-MS, Elan DRC II Perkin Elmer). The stability of the apparatus was controlled by a solution of Elan 6100 DRC Setup/Stab/Masscal: $1 \mu \mathrm{g} \mathrm{L}^{-1} \mathrm{Mg}, \mathrm{Al}, \mathrm{Cr}, \mathrm{Mn}, \mathrm{Cu}, \mathrm{Rh}, \mathrm{Cd}, \mathrm{In}, \mathrm{Ce}, \mathrm{Pb}$, Th and a $10 \mu \mathrm{g} \mathrm{L}^{-1}$ of $\mathrm{Ba}$ in $0.5 \% \mathrm{HNO}_{3}$.

The flow rate was fixed at $20 \mathrm{~mL} \mathrm{~min}^{-1}$ and the calibration curve was achieved with seven points ranging from 1 to $100 \mu \mathrm{g} \mathrm{L}{ }^{-1}$ with the isotopes ${ }^{61} \mathrm{Ni},{ }^{66} \mathrm{Zn},{ }^{208} \mathrm{~Pb},{ }^{63} \mathrm{Cu},{ }^{112} \mathrm{Cd}$, ${ }^{114} \mathrm{Cd}$. Every sample was measured in triplicate. The method quantification limit was $0.45 \mu \mathrm{g} \mathrm{L}{ }^{-1}$ for ${ }^{66} \mathrm{Zn}, 0.006 \mu \mathrm{g} \mathrm{L}{ }^{-1}$ for ${ }^{208} \mathrm{~Pb}, 0.01 \mu \mathrm{g} \mathrm{L}{ }^{-1}$ for ${ }^{65} \mathrm{Cu}, 0.01 \mu \mathrm{g} \mathrm{L}{ }^{-1}$ for ${ }^{111} \mathrm{Cd}$ and ${ }^{61} \mathrm{Ni}$.

\subsection{Electroanalytical techniques}

Electroanalytical techniques (polarography, potentiometry) were used for studying the interactions between $\mathrm{OM}$ and metal ions and to measure the labile concentrations of metals.

Voltamograms were recorded using an Autolab potentiostat (PGSTAT-12 controlled by GPES 4.9 software from EcoChemie, Netherlands) connected to a Metrohm 663 VA electrode stand (Metrohm, Herisau, Switzerland). Static Mercury Drop Electrode (SMDE mode) as indicating electrode, a platinum counter electrode and an $\mathrm{Ag} / \mathrm{AgCl}$ (sat. $\mathrm{NaCl}$ ) electrode as a reference were used. Before each measurement, the solution in the polarographic cell was deaerated with high purity nitrogen for 5 minutes. Stirring of the solution was performed by Teflon stirrer rotating at $3000 \mathrm{rpm}$. The room temperature was maintained at $22 \pm 1^{\circ} \mathrm{C}$.

The polarographic titrations were carried out with an automatic burette (Metrohm Dosimat 665) containing a multielements solution freshly prepared and acidified with nitric acid: $[\mathrm{Zn}]=[\mathrm{Pb}]=[\mathrm{Cd}]=2.5 \mu \mathrm{mol} \mathrm{L}^{-1},[\mathrm{Cu}]=25 \mu \mathrm{mol} \mathrm{L}^{-1}$. The method set up entailed six additions of $25 \mu \mathrm{L}$ of metal to a $50 \mathrm{~mL}$ sample and aimed at determining the pseudo-total metal concentrations (after acidification at $\mathrm{pH}=2$ of the solutions by $\mathrm{HNO}_{3} 70 \%$. All solutions were prepared in deionised water. Metal solutions were prepared by diluting a commercial standard solution $\left(1.0 \mathrm{~g} \mathrm{~L}^{-1}\right.$, Fluka, Buchs) under nitrate salts form. Before any sample measurement, a blank sample consisting of deionised water acidified with nitric acid was run. The multielements solution was measured as well at various times interval to evaluate the metal adsorption problem on flasks walls. Quantification limit for this analytical method was experimentally determined to be equal or less than $0.1 \mu \mathrm{g} \mathrm{L}^{-1}$.

Differential pulse anodic stripping voltammetry was used to study the interactions between NOM and metal ions by measuring directly the free and labile fraction of metal. Usual procedure involves successive known additions of the selected metal to the samples $(50 \mathrm{~mL})$. The logarithmic addition of metal was performed in the range $2.5 \times 10^{-10} \mathrm{~mol} \mathrm{~L}^{-1}$ to $1.11 \times 10^{-6} \mathrm{~mol} \mathrm{~L}^{-1}$. The advantage of logarithmic additions is the significant improvement of the titration accuracy at low metal concentrations [26]. Indeed, the biggest complexation effects are taking place at lowest concentrations, as 


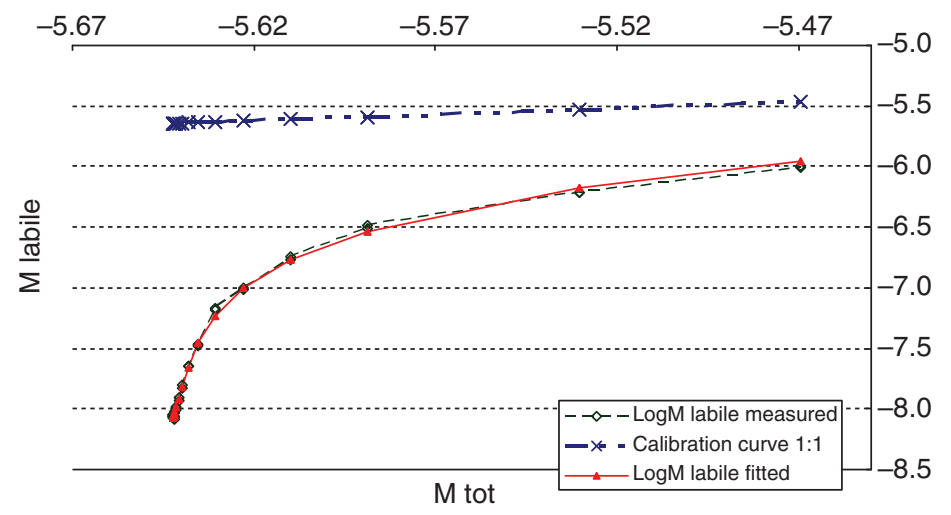

Figure 3. Experimental and fitted polarographic data for the D65 sample $\left(25^{\circ} \mathrm{C}\right)(\mathrm{M}$ : concentration of metal in $\mathrm{mol} \mathrm{L}^{-1}$ ).

indicated in Figure 3, for the D65 sample. Voltammograms were registered after each addition of metal (16 additions were made in total).

After each addition of metal, a $\mathrm{N}_{2}$ purge was delivered for $30 \mathrm{~s}$ followed by a metal preconcentration step at $-1.2 \mathrm{~V}$ during $300 \mathrm{~s}$. An equilibration time where stirring is stopped was set to $10 \mathrm{~s}$ maintaining a potential of $-1.0 \mathrm{~V}$. A potential range from $-1.0 \mathrm{~V}$ to $0.001 \mathrm{~V}$ was then imposed with a potential step of $0.002 \mathrm{~V}$. Errors on measurements were calculated based on three replicates and never exceeded $5 \%$. The study of complexes between natural organic matter (NOM) and metals by logarithmic additions was carried out at natural $\mathrm{pH}$ (ranging from 7.5 to 8.5 ).

The kinetic of complexation between metal and OM was evaluated by DPASV to determine the time to elapse between two successive metal additions to let the system equilibrate. We determined the kinetic rate on $30 \mathrm{~mL}$ of natural sea samples at the lowest and highest concentrations: $2.5 \times 10^{-10} \mathrm{~mol} \mathrm{~L}^{-1}$ and $1.11 \times 10^{-6} \mathrm{~mol} \mathrm{~L}^{-1}$ of $\mathrm{Cu}\left(\mathrm{NO}_{3}\right)_{2}$. We recorded a voltamogram every 5 minutes until they superimposed. The kinetic of complexation was found to be $1 \mathrm{~h}$ for $2.5 \times 10^{-10} \mathrm{~mol} \mathrm{~L}^{-1}$ and $15 \mathrm{~min}$ for $1.11 \times 10^{-6} \mathrm{~mol} \mathrm{~L}^{-1}$. Theses equilibration times were applied in the method between two successive metal additions in the procedure described previously.

Potentiometric titrations were performed using an automatic titration set-up consisting of a thermostatic titration cell (kept at $25.0 \pm 0.1^{\circ} \mathrm{C}$, Fisher), a combined electrode (glass$\mathrm{Ag} / \mathrm{AgCl}$, Mettler-Toledo Inlab 422), Motor-driven Piston Burettes (2 Titrino 719S Metrohm) controlled by computer (Program Tinet 2.4), and a stirring system (728 Metrohm). The electrode was calibrated with 3 buffer solutions at 4.01, 7.01 and 10.01 (Hanna). The $\mathrm{NaOH}$ titrant was prepared at $0.1 \mathrm{~mol} \mathrm{~L}^{-1}$ from a $1 \mathrm{~mol} \mathrm{~L}^{-1}$ standard solution.

Titrations of $40 \mathrm{~mL}$ of samples were achieved by increment of $50 \mu \mathrm{L}$ of titrant at a speed of $0.5 \mathrm{~mL} \mathrm{~min}^{-1}$ after an equilibration time of $30 \mathrm{~s}$. The ionic strength of the samples was imposed by itself due to the high concentration of $\mathrm{NaCl}$ salt $\left(38 \mathrm{~g} \mathrm{~L}^{-1}\right)$. A $\mathrm{N}_{2}$ stream was maintained over the solution to avoid $\mathrm{CO}_{2}$ dissolution during the titration. Each addition of titrant was followed by the measurement of the drift over a 2 min interval. If the drift was less than $0.2 \mathrm{mV} \mathrm{min}^{-1}$, the $\mathrm{pH}$ value was accepted and the next addition of 
titrant was made. A maximum time of $15 \mathrm{~min}$ was fixed between two successive additions of titrant.

All the analytical methods used for the determination of carbon and metal concentrations, were tested in term of quality assurance according to classical statistical methods and standard operating procedures for validation of a method. Accuracy was evaluated based on commercial reference standards (certified metal standards from SPEX CertiPrep Assurance) measured with the analytical method used. Evaluation of the precision was done with the standard deviation parameter calculated with several successive measurements.

\subsection{Fluorescence}

Samples corresponding to the $1 \mathrm{kDa}$ retentate fractions were analysed by $3-\mathrm{D}$ fluorescence. Fluorescence spectra were recorded on a Hitachi F-4500 fluorescence spectrometer with Xenon lamp, equipped with a thermostatic cell and connected to a peristaltic pump. The values of $\mathrm{pH}$ were monitored all along the measurements by a glass electrode Mettler Toledo Inlab 422 combined with an $\mathrm{Ag} / \mathrm{AgCl}$ reference electrode (Mettler Toledo Inlab 302). A quartz cell of $1 \mathrm{~cm}$ was used and the experiments were achieved on $5 \mathrm{~mL}$ of $1 \mathrm{kDa}$ retentates fractions to get strong signal intensity. The excitation wavelength $\lambda_{\text {ex }}$ ranged from 200 to $500 \mathrm{~nm}$, the emission wavelength $\lambda_{\text {em }}$ ranged from 250 to $500 \mathrm{~nm}$, with a wavelength interval of $5 \mathrm{~nm}$. The scan speed was $2400 \mathrm{~nm} \mathrm{~min}^{-1}$. 3D-fluorescence spectra (EEM: Emission-Excitation Matrix) were achieved on each sample to determine the $\lambda_{\text {ex }}$ and $\lambda_{\text {em }}$ of maximum signal intensity. Duplicates samples were analysed to ensure the results. The quenching of fluorescence (2-D spectra) was then carried out by fixing the $\lambda_{\text {ex }}$ corresponding to the maximum intensity found on the $3 \mathrm{D}$ spectrum and scanning the $\lambda_{\mathrm{em}}$ within the interval of maximum signal emission wavelength. The scan speed for the quenching experiment was reduced to $240 \mathrm{~nm} \mathrm{~min}^{-1}$ and 30 additions of metal ions with increasing concentrations were made in a logarithmic mode to get better precision on lowest concentrations of metal. Between two samples, the quartz cell was rinsed with $\mathrm{HClO}_{4} 10 \%$ and then deionised water. The spectra were obtained by subtracting deionised water blank spectra recorded under the same conditions to eliminate water Raman scatter peaks.

Logarithmic additions of metal were achieved to the samples with a Metrohm stand equipped with three dosinos (700 Metrohm) containing a nirate copper solution at 0.9 , 0.09 and $0.009 \mathrm{mmol} \mathrm{L}^{-1}$. An additional $716 \mathrm{DMS}$ Titrino containing $25 \mathrm{mmol} \mathrm{L}^{-1} \mathrm{NaOH}$ solution was connected to the system in order to maintain the $\mathrm{pH}$ at 6.0. This $\mathrm{pH}$ was chosen to avoid any hydrolysis phenomenon that could interfere with the complexation process between the NOM and the metal ion. Furthermore, the $\mathrm{pH}$ had to be maintained constant since it was shown that the fluorescence signal was dependent on it [27].

\subsection{Modelling}

In order to understand the origins of the DOC, the main differences between them and their binding affinity towards metals, electroanalytical (polarography and potentiometry) and fluorescence techniques were used. The data obtained were fitted to extract NOM and NOM-metal complexes specific parameters. 
Modelling of voltammmetric data was achieved using PROSECE software (Programme d'Optimisation et de SpEciation Chimique dans l'Environnement, University of Toulon [28]). It uses a discrete model for the description of the OM proton distribution. It has been written on the basis of the numerical calculation program Octave (freeware) and uses a speciation program coupled to an optimisation program. The speciation calculation is based on mass balance resolution by the Newton-Raphson optimisation method, after Morel's table is defined [29]. Modelling of the DPASV data was performed taking into account the global addition pattern, compared to a reference one (calibration). The difference between the calibration curve $\left(\log \mathrm{M}_{\mathrm{to}} \mathrm{t}=\mathrm{f}\left(\log \mathrm{M}_{\mathrm{tot}}\right)\right)$ and the experimental curve $\left(\log \mathrm{M}_{\text {tot }}=\mathrm{f}\left(\log \mathrm{M}_{\text {labile }}\right)\right)$ is proportional to the extent of complexation with DOC. $\mathrm{M}_{\text {tot }}$ is the total concentration of metal, corresponding to the sum of the initial metal concentration present in the sample and the metal concentration added [26].

PROSECE was used for the fitting of the potentiometric titrations to reach proton dissociation constants of OM. The titrations modelling simulated a set of six ligands to try to get more information on the distribution of the dissociation constants of the proton.

A discrete model describing the OM binding sites was also used for the modelling of DPASV and fluorescence quenching experiments: the presence of one global ligand (L) was simulated. Its concentration and the stability constants with the metal ions were optimised. The program PROSECE was applied in all the DPASV fittings [26]. For the fluorescence modelling, the simulated experimental data points were improved from the methods of Chau-Buffle [22,30]. Ryan and Weber [31] described into details the theory used to fit the fluorescence quenching of a ligand in solution by a metal ion in order to extract the complexation parameters: stability constant and concentration of fluorescing binding sites. The simple 1:1 metal: ligand stoichiometry was assumed, which led to mean values over the whole polydisperse OM ligands. This simple model does not reflect the structural complexity of the OM, but it allows comparison of the samples to each other.

\section{Results}

\subsection{Evolution of metal content in the dissolved phase}

The metal contents in the dissolved phase of the various samples are shown in Figure 4, for $\mathrm{Pb}, \mathrm{Cu}, \mathrm{Zn}$ and $\mathrm{Cd}$. The blank measurements were subtracted from the sample measurements for any analytical techniques used and were found to be less than $10 \%$ of the values in the samples.

The reference point (M06) collected in the middle of the lagoon should be free of any metal content, considering the distance that separates it from the shore (Figure 1, New Caledonia sampling sites). However, this site exhibits a concentration of $11 \mu \mathrm{g} \mathrm{L}^{-1}$ in $\mathrm{Cu}$, which is higher than the regular values expected for a lagoon or a sea [32], even though this concentration remains lower than the ones considered as critical for the environment $\left(30 \mu \mathrm{g} \mathrm{L}^{-1}\right)$ [33].

In general, the garbage dump sample (D65) ended up with the highest levels for all the metals studied: $\mathrm{Ni}, \mathrm{Zn}, \mathrm{Pb}, \mathrm{Cu}$ and $\mathrm{Cd}$. Batteries, rubber decomposition, plumbing pipes and domestic wastes are likely to be responsible for such pollution. The St Marie Bay site (N04) was found to be quite problematic as well, since $\mathrm{Cd}, \mathrm{Pb}$ and in lower extent $\mathrm{Zn}$, were found in the highest concentrations at this location. The little harbour in St Marie Bay, in addition to the $\mathrm{Zn}$ roofs of the houses along the shore, the domestic wastewater and the sewage pipes washed off by detergents are probably at the origin of these metal inputs 

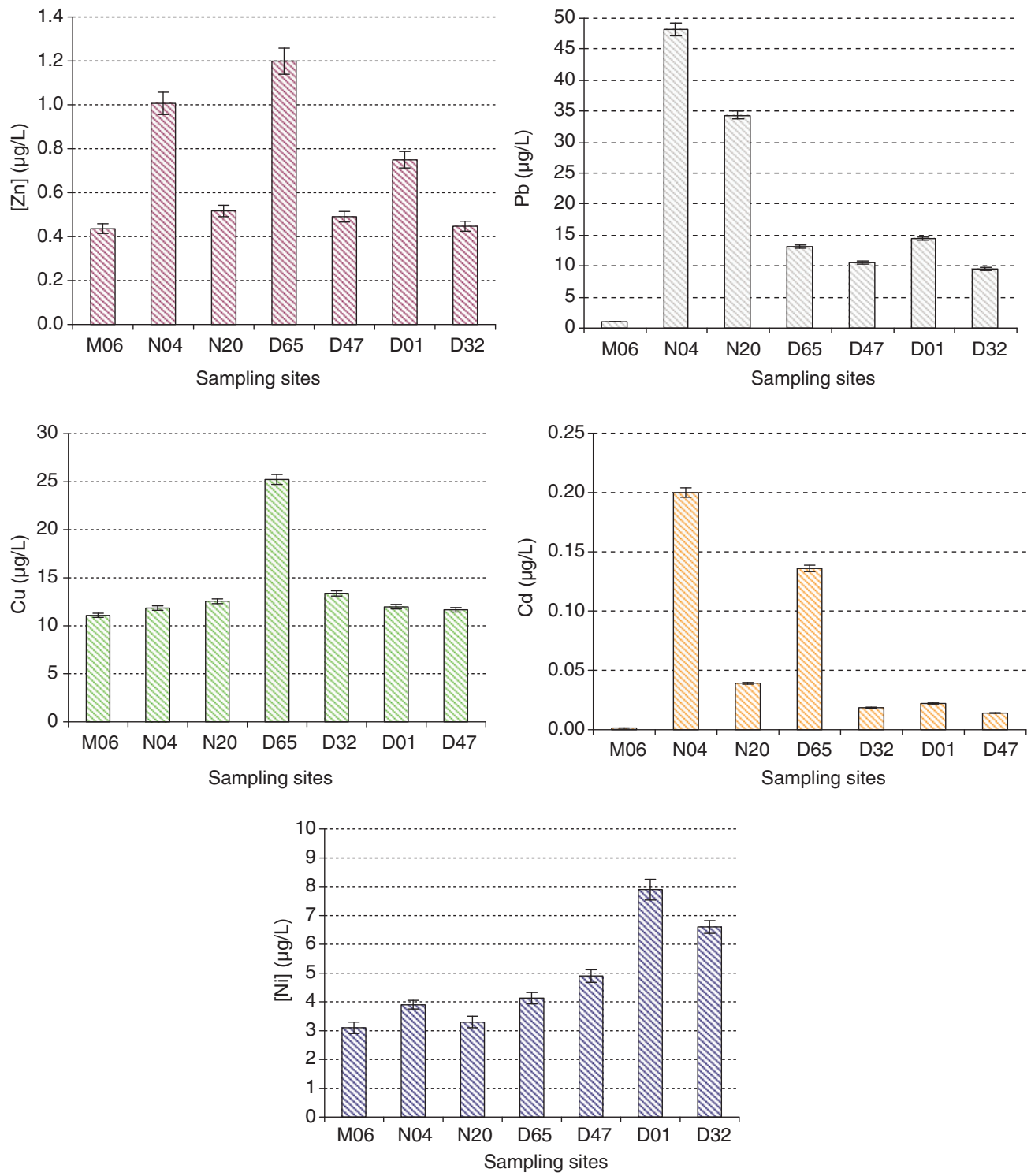

Figure 4. Dissolved phase heavy metal concentrations in the various sampling sites (in $\mu \mathrm{g} / \mathrm{L}$ ).

within this area. Furthermore, St Marie Bay is quite narrow, which does not in favour of dilution processes. Finally, the presence of a high level of dissolved carbon in this location is likely to favour the transport of metals farther offshore (along the N04 to N20 transect). It is important to point out that the residence site (sample collected $2 \mathrm{~m}$ from the shore) was particularly polluted by nitrate and sulphate ions (measured in parallel by ionic chromatography). About 1.7 to 2.0 times more ions than in the reference sample (M06) were found in this location. Eutrophication is a consequence of such concentrations and 
shows the detrimental impact of wastewater discharged into the lagoon. Nevertheless, dilution was rapidly observed gradually as the distance from the shore increased.

The metal inputs in the industrial SLN area (D01) mainly concerned $\mathrm{Ni}$ and $\mathrm{Pb}$. It is very likely that natural source of $\mathrm{Ni}$ from soil leaching into the lagoon was responsible for such concentrations. Furthermore, Dumbea River is likely to represent a natural source of $\mathrm{Ni}$ in Koutio Bay, as shown by the higher level of Ni in D47 sampling site. Migon [34] found the same order of magnitude for Ni concentration in dissolved phase in another part of New Caledonia lagoon, and observed a dilution effect close to the coral barrier reef. Furthermore, the SLN zone (D01) showed low content of Cd but higher than the reference (M06), showing an anthropogenic input.

Dilution effects were visible from the metal input sources on the shore, showing a transport along the shore or towards the lagoon according to the current and wind effects. Dilution effects (D47, D32, N20) allowed the concentrations to decrease back to the reference values for $\mathrm{Zn}$ and $\mathrm{Cu}$ while $\mathrm{Cd}, \mathrm{Pb}$ and $\mathrm{Ni}$ maintained concentrations over the reference point (M06).

Generally, all the sites remained very moderate in metal content, and should not be an issue for the environment. The monitoring of these heavy metals should however be monitored, considering the low tolerance of some of them (especially Cd) for marine living organisms [35].

The transport of metal ions can be led by not only dissolved OM, but also particulate OM. The distribution between these two phases will give information on the immobilisation or transport capacity of these metals, and on the prediction of an eventual accumulation in sediments. In this respect, metal content was analysed in solid phase, as shown in the following section.

\subsection{Evolution of metal content in the solid phase}

The metal contents in the solid phase of the various samples are shown in Figure 5. Zn was in highest concentration in the particulate phase. A clear input could be seen in the residence site (N04) but mostly at the SLN location (D01). A decrease in metal concentration as we get farther from the coastline (N20, D32) indicated various possible phenomena: sedimentation, desorption of the metals from the particles, and/or a dilution due to another contribution source of metal-free particles. No additional input at the garbage dump in $\mathrm{Zn}$ was evidenced in the particulate phase.

$\mathrm{Pb}$ and $\mathrm{Cu}$ inputs in the particulate phase were evidenced at the garbage dump (D65), the residence site (N04), and over all, as for Zn, at the SLN area (D01) (which corresponds to anthropogenic zones, close to the shore), with a decrease in metal concentrations farther offshore (D47, N20, D32). Transport of lead in the solid phase from D01 to D32 seemed to be particularly problematic considering the toxicity and level of $\mathrm{Pb}$ still present in $\mathrm{D} 32$. These results showed that there was an anthropogenic source of lead in these areas, as indicated as well in the dissolved phase results. Consequently, we can expect relatively high level of lead in the sediments nearby these locations, especially along the transect from D01 (Figure 1, New Caledonia sampling sites). According to the results of Dalto [36] this transect was the most affected by lead and a level around $52 \mu \mathrm{gg}^{-1}$ of lead was found in the sediments nearby the D01 site.

SLN (D01) had the highest level of $\mathrm{Ni}\left(320.2 \mu \mathrm{g} \mathrm{g}^{-1}\right)$ and $\mathrm{Cd}\left(2.85 \mu \mathrm{g} \mathrm{g}^{-1}\right)$ followed by residence (N04). Surprisingly, the garbage dump (D65) did not seem to represent a Cd 

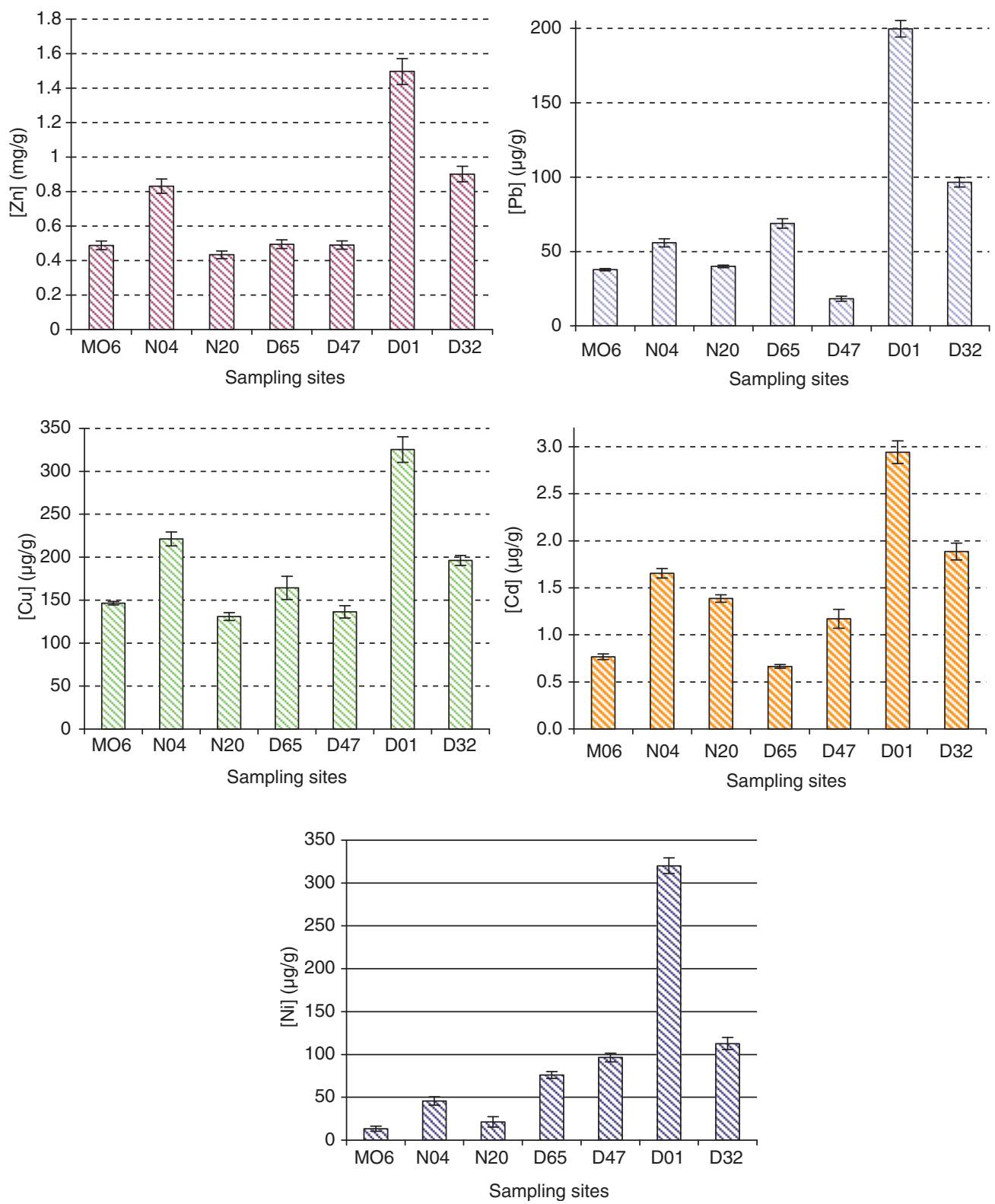

Figure 5. Solid phase heavy metal concentrations in the various sampling sites (in $\mathrm{mg} / \mathrm{g}$ for $\mathrm{Zn}$ and in $\mu \mathrm{g} / \mathrm{g}$ for $\mathrm{Pb}, \mathrm{Cu}, \mathrm{Cd})$.

source while D47, located farther from the coastline, is higher not only in $\mathrm{Cd}$ but also in Ni. It looked like the Dumbea River could bring not only Ni (from natural Ni-rich soil erosion) but also some $\mathrm{Cd}$ (which originates from human activities) through the leaching process. Different studies such as Metian [37] or Hédouin [23] highlighted that Cd concentrations in bivalves in their references sites were higher than supposedly 
contaminated sites in Noumea surroundings. These results can be explained by terrigenous inputs deposited in the stream of Dumbea River and then resuspended under the concomitant influence of tides and winds [38]. However, the concentrations of $\mathrm{Cd}$ in the solid phase generally remained low for all the samples.

Considering the quality guideline NOAA [39-40] referencing the levels of toxicity for heavy metals, we can consider a clear pollution in Ni (NOAA limit tolerated: $51.6 \mu \mathrm{g} \mathrm{g}^{-1}$ ) for the D65, D47, and D01 (with its corresponding dilution site D32). D01 can be as well considered as a polluted area in $\mathrm{Cu}$ and $\mathrm{Zn}$ with concentrations exceeding the limit values recommended by the NOAA $\left(270 \mu \mathrm{gg}^{-1}\right.$ for $\mathrm{Cu}$ and $410 \mu \mathrm{gg}^{-1}$ for $\left.\mathrm{Zn}\right)$. These metal concentrations in suspended matter are transported farther from the pollution source and are expected to have a significant impact on metal content in sediments and, as a consequence, affect living organisms, as demonstrated by the work by Dalto et al. [36].

\subsection{Evolution of carbon content in dissolved and solid phases}

\subsubsection{Solid phase}

Understanding $\mathrm{OM}$ properties and their interactions in the environment can lead to a better understanding of dissolved and particulate OM properties, such as proton and metal ion binding, pesticide and polycyclic aromatic hydrocarbon interactions [41-42] and the effect of $\mathrm{OM}$ on the ecosystem [43]. Total organic carbon concentration has been widely used as a classical method for measuring OM [44], although it has little discriminatory power since it cannot distinguish between carbon fractions.

The evolution of the POC concentration (in $\mathrm{mg} / \mathrm{L}$ ) as a function of the sampling sites is presented in Figure 6a. It is clear that the inputs in organic particulates were much higher inshore (residence (N04), garbage dump (D65) and SLN (D01)). Indeed, the coastline is more susceptible to wind effect coming from the land, generating resuspension of sediments (due to shallow level of water). Terrigenous inputs are also responsible for the presence of suspended matter nearby the shore, especially during rainy season [45].

Furthermore, we can notice that the POC levels in the reference (M06) and the sites located farther from the shore (N20, D47, D32) were of the same order of magnitude: these locations suffer less turbulences at the surface due to lower boat activity and deeper streams. As a consequence, particulates were not remobilised in suspension at $1 \mathrm{~m}$ depth.

On top of the previous samples discussed above, more samples were collected $2 \mathrm{~m}$ from the coastline (named garbage dump, residence and Dumbea on the map, Figure 1) in order to check in detail the dilution of the Suspended Matter (SM) and POC (Figure 6c) along the transects. The POC levels were significantly decreasing as we got farther from the shore, in the transect lines (Figure 6c), until we reached the reference value in the middle of the lagoon (M06). In particular, the sample of each transect collected the closest to the shore (garbage dump, residence, SLN and Dumbea) exhibited significantly higher levels of $\mathrm{SM}$ and POC than the other samples (from twice to four times as much). Two phenomena may explain SM or POC level drops: dilution (by getting farther from the source of pollution) or flocculation induced by increasing salt level [46]. Considering the salinity of each sample, only Dumbea River sample (fresh water) and Residence sample (both collected $2 \mathrm{~m}$ from the shore) exhibited lower levels of $\mathrm{NaCl}$. Consequently, dilution is the process by which SM and POC levels are dropping. Moreover, as a consequence of this result, we can expect a high concentration of heavy metals accumulated in the sediments within at least 50 to $100 \mathrm{~m}$ from the shore. The peaks of suspended matter found in the 

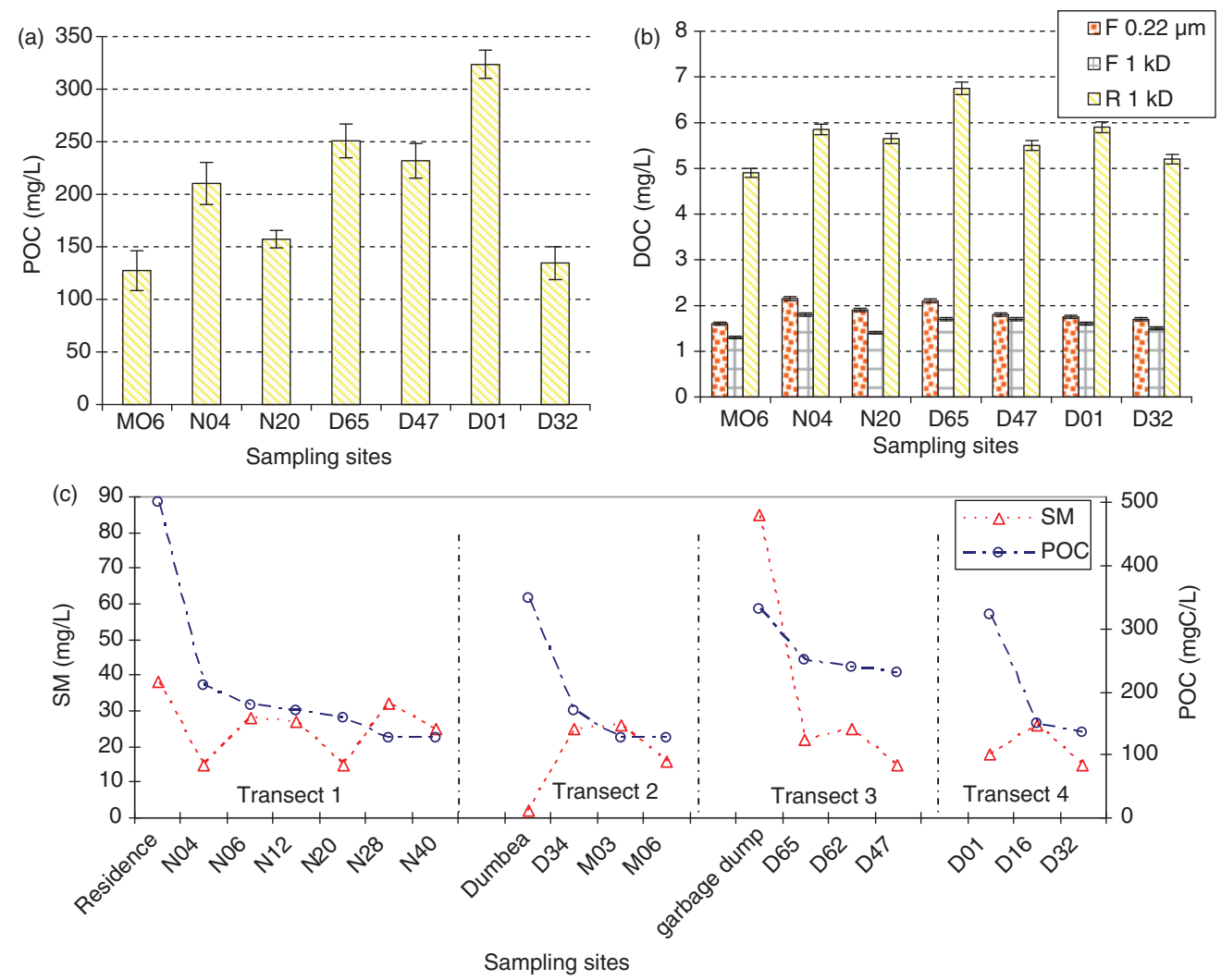

Figure 6. Evolution of (a) POC, (b) DOC and (c) SM in the various sampling sites (mg/L) (F1kD and R1kD: Filtrate and Retentate $1 \mathrm{kD}$; F0.22: Filtrate $0.22 \mu \mathrm{m}$; POC and DOC: Particulate and Dissolved Organic Matter; SM: Suspended Matter).

garbage dump area and residence sites collected $2 \mathrm{~m}$ from the coastline $(3 \mathrm{~km}$ before D65 and $0.5 \mathrm{~km}$ before N04) were clearly the result of urban activities.

At the mouth of Dumbea River, we noticed a clear drop in SM, but at the same time a peak in POC. This result indicates the presence of carbon-rich particulates that probably originate from the natural sediments coming from the spring water of the river stream. Indeed, Dumbea is located far from any urban or industrial activity. These particulates can act as natural ligands for the transport of metals originating from soil or rock leaching.

In the garbage waste, the particulates were also rich in carbon compared to the other samples, but, contrary to the Dumbea River, they could be of anthropogenic origin, considering the surrounding of the site. Moreover, soil leaching could explain these concentrations, especially considering the land slope existing between the garbage wastes and the water.

We noticed that the SLN site (D01) had as much carbon as the garbage dump (D65) while it presented less suspended matter, which suggests that we are in presence of different nature of particulates, both anthropogenic.

The SLN site was outstanding since its metal and POC (about $325 \mathrm{mgC} \mathrm{L}^{-1}$ ) concentrations level were much higher than in the other locations. It seems to indicate that 
the metals are accumulating in the particulate phase. There is a remobilisation of particulates in suspension, probably due to sewage pipes located nearby the Company. Furthermore, a trade harbour, nearby the SLN Company, is responsible for big merchant ship traffic that would generate water turbulences, and must remobilise the sediments in suspension, especially in this shallow location.

\subsubsection{Dissolved phase}

The evolution of the DOC (in $\mathrm{m} \mathrm{L}^{-1}$ ) as a function of the sampling sites is presented in Figure 6b. It indicates that the ultrafiltration of the samples was efficient since the NOM was concentrated by a factor of 3.5 on average.

The DOC measured in the samples, for example in the $1 \mathrm{kDa}$ retentate fraction, showed that the garbage dump station (D65), the residence site (N04) and the SLN Company samples (D01) were rich in DOC, originating from urban and industrial activities. Maximum level of DOC was found at the garbage dump site (D65). Furthermore, the dilution effect of DOC was well indicated, even though the reference level was never reached back after dilution (D32, N20, D47). No direct correlation seemed to exist between the metal and the DOC according to these data, when comparing their evolutions in parallel. On the contrary, the POC values seemed to be correlated to the evolution of the metal in the different sites of sampling.

In natural waters, $\mathrm{Fe}, \mathrm{Zn}$ and $\mathrm{Pb}$ were shown to have a strong affinity for particulates [47-48] while $\mathrm{Cu}$ was more associated with dissolved organic matter. In our case, the partition coefficient $\mathrm{P}\left(\mathrm{P}=[\mathrm{M}]_{\text {dissolved }} /\left[\mathrm{M}_{\text {solid }}\right]\right)$ was found between 0.001 and 0.006 for both $\mathrm{Pb}$ and $\mathrm{Zn}$ while it was in the range 0.26 to 0.84 for $\mathrm{Cu}$. Partition coefficients were ranging from 0.02 to 0.23 for $\mathrm{Ni}$, and from 0.01 to 0.20 for $\mathrm{Cd}$. The comparison of the partition coefficients between dissolved and solid phases indicates clearly that all metals studied have a better affinity for the solid phase, but in much greater extent for $\mathrm{Zn}$ and $\mathrm{Pb}$. Consequently, the metal pollution would preferentially accumulate in the sediments. This is in accordance with Vasquez [49].

\subsection{Natural marine versus anthropogenic type OM}

\subsubsection{D-florescence spectra}

Samples corresponding to the $1 \mathrm{kDa}$ retentate fractions were analysed by 3-D fluorescence. The spectra showed three peaks (Figure 7). According to the literature, they correspond to the so-called peak A, peak C/M and protein-like peak (see Table 1) [50]. The peaks A and $\mathrm{C} / \mathrm{M}$ originate from a major contribution of fulvic and humic acids-like molecules respectively. The fluorescence emission and excitation wavelengths $\left(\lambda_{\mathrm{em}}, \lambda_{\mathrm{ex}}\right)$ of the signals found in all the samples were summarised in Table 2.

Table 2 shows that excitation and emission fluorescence wavelengths of both peaks A and $\mathrm{C} / \mathrm{M}$ in residence farther (D47) and SLN farther (D32) samples were very similar to the reference one (M06). They were collected the farthest from the shore. The hypothesis that NOM of these samples are of pure marine origin can therefore be made. These wavelengths would correspond to peak $\mathrm{M}$ according to Coble [50], considering the range of $\lambda_{\text {em }}$ and $\lambda_{\text {ex }}$.

The sample residence farther (N20) presented a spectrum similar to the reference one (M06) as well. We can conclude that the OM would be of marine origin as well, due to 




Figure 7. Emission Excitation Matrix (EEM) fluorescence spectrum of D65 sample $\left(25^{\circ} \mathrm{C}\right)$.

Table 1. Main OM fluorescence signals according to their origin (Coble, 1995).

\begin{tabular}{lccl}
\hline Signals & $\lambda_{\text {em } \max }(\mathrm{nm})$ & $\lambda_{\text {em max }}(\mathrm{nm})$ & \multicolumn{1}{c}{ Type of compounds } \\
\hline B & $270-280$ & $300-320$ & Proteinic type, tyrosine \\
T & $270-280$ & $320-350$ & Proteinic type, tryptophane \\
A & $250-260$ & $380-460$ & Fulvic type \\
M & $310-320$ & $380-420$ & Humic type from sea water \\
C & $330-350$ & $420-480$ & Humic type \\
\hline
\end{tabular}

Table 2. Emission and Excitation wavelengths of the fluorescence signals $\left(\lambda_{\mathrm{em}}, \lambda_{\mathrm{ex}}\right)$ as a function of the sampling sites.

\begin{tabular}{llllllll}
\hline & & \multicolumn{2}{c}{ A Signal } & & \multicolumn{2}{c}{ C/M Signal } & \\
\cline { 3 - 4 } Sampling sites & $\lambda_{\text {ex }}(\mathrm{nm})$ & $\lambda_{\mathrm{em}}(\mathrm{nm})$ & & $\lambda_{\mathrm{ex}}(\mathrm{nm})$ & $\lambda_{\mathrm{em}}(\mathrm{nm})$ & & OM origin \\
\hline M06 & Reference & 240 & 420 & & 312 & 406 & Marine \\
N04 & Residence & 247 & 430 & & 314 & 435 & Anthropique \\
N20 & Residence further & 245 & 416 & & 311 & 405 & Marine \\
D65 & Garbage dump & 245 & 433 & & 318 & 440 & Anthropique \\
D47 & Garbage dump further & 240 & 416 & & 318 & 425 & Anthropogenic \\
D01 & SLN & 245 & 410 & & 313 & 415 & Anthropique \\
D32 & SLN further & 245 & 416 & & 312 & 406 & Marine \\
\hline
\end{tabular}

dilution effect with pure marine water. It seems that long-distance OM transport from the residence (N04) in dissolved phase is limited, unless it is very diluted.

The fluorescence wavelengths of the peak C corresponding to the residence (N04), garbage dump (D65) and SLN (D01) samples (Table 2) differed significantly from the peak $\mathrm{M}$ of the reference (M06). This indicates that the OM in these samples was not of marine origin but of anthropogenic origin considering the sites of sampling. Industries, domestic wastes, urban wastes are probably responsible for such signals. According to the signal wavelengths, this OM is not likely to originate from soil leaching [51]. The fluorescence 
Table 3. Modelling results of the potentiometric titrations.

\begin{tabular}{lcccccccc}
\hline & & M06 & N04 & N20 & D65 & D47 & D01 & D32 \\
\hline pKa & $\mathrm{L}_{1}$ & 2.16 & 2.14 & 2.51 & 1.86 & 1.46 & 1.67 & 1.92 \\
& $\mathrm{~L}_{2}$ & 2.53 & 5.88 & 3.77 & 3.85 & 2.34 & 4.59 & 3.01 \\
& $\mathrm{~L}_{3}$ & 5.75 & 5.71 & 5.09 & 5.76 & 4.98 & 5.85 & 5.18 \\
& $\mathrm{~L}_{4}$ & 5.63 & 8.57 & 5.76 & 7.76 & 5.92 & 8.32 & 5.94 \\
& $\mathrm{~L}_{5}$ & 8.31 & 9.85 & 8.43 & 8.56 & 8.75 & 8.59 & 7.96 \\
& $\mathrm{~L}_{6}$ & 10.62 & 10.62 & 10.54 & 10.28 & 10.63 & 10.99 & 9.91 \\
[Ligand] $\left(\mathrm{mmol} \mathrm{L}^{-1}\right)$ & $\mathrm{L}_{1}$ & 0.091 & 0.206 & 0.092 & 0.409 & 0.498 & 0.463 & 0.271 \\
& $\mathrm{~L}_{2}$ & 0.040 & 0.015 & 0.0001 & 0.0001 & 0.012 & 0.005 & 0.001 \\
& $\mathrm{~L}_{3}$ & 0.005 & 0.019 & 0.002 & 0.042 & 0.001 & 0.035 & 0.013 \\
& $\mathrm{~L}_{4}$ & 0.032 & 0.133 & 0.036 & 0.001 & 0.038 & 0.0002 & 0.026 \\
& $\mathrm{~L}_{5}$ & 0.033 & 0.0001 & 0.034 & 0.036 & 0.042 & 0.039 & 0.015 \\
& $\mathrm{~L}_{6}$ & 0.349 & 0.328 & 0.288 & 0.178 & 0.322 & 0.636 & 0.188 \\
Site density $\left(\mathrm{mmol} \mathrm{L}^{-1}\right)$ & 0.55 & 0.70 & 0.45 & 0.67 & 0.91 & 1.18 & 0.51 \\
\hline
\end{tabular}

peaks of the garbage dump (D65) and SLN (D01) samples were particularly different, indicating a more specific input coming from industrial activity and the organic garbage wastes.

\subsubsection{Potentiometric data modelling}

Table 3 gives the results obtained after modelling the potentiometric titrations with PROSECE, simulating sixdiscrete ligands, likely to complex metal ions as a function of their pKa. The residence farther (N20) and the reference (M06) presented very similar acido-basic properties, based on their $\mathrm{pKa}$ distribution and site densities. This result confirms the hypothesis formulated from the fluorescence spectra: both samples are of marine type OM. The dilutions from N04 (residence) and D01 (SLN) samples resulted in a downwardshift of the acido-basic parameters of the samples N20 (residence farther) and D32 (SLN farther) respectively, leading them towards the reference (M06) ones. Potentiometric titrations confirmed hence a clear dilution effect with marine OM. These results tend to show that $\mathrm{OM}$ originating from pure marine water presents less compounds to complex metal ions, whereas anthropogenic OM have the ability to complex more.

L2 and L4 ligands pKa values obtained from potentiometric titrations (Table 3) of the residence (N04, 5.88 and 8.57 for L1 and L2), SLN (D01, 4.59 and 8.32 for L1 and L2) and garbage dump (D65, 3.85 and 7.76 for L1 and L2 respectively) differed tremendously from the reference (M06, 2.53 and 5.63 for L1 and L4 respectively), which confirms the anthropogenic origins of the organic matter in these samples. Furthermore, the garbage dump (D65), farther on from the garbage dump (D47) and SLN (D01) samples exhibited significant differences in both $\mathrm{pKa}$ and site densities values compared to the reference for the ligand 1. The latter was clearly more acidic than the reference one (M06), and the corresponding site density was much higher. Consequently, it seems that anthropogenic $\mathrm{OM}$ would have the ability to complex more metal ions and at more acdic $\mathrm{pH}$ compared to the reference. These results confirmed that the OM of the garbage dump (D65), farther on from the garbage dump (D47) and SLN (D01) are not of marine origin. Industrial and 


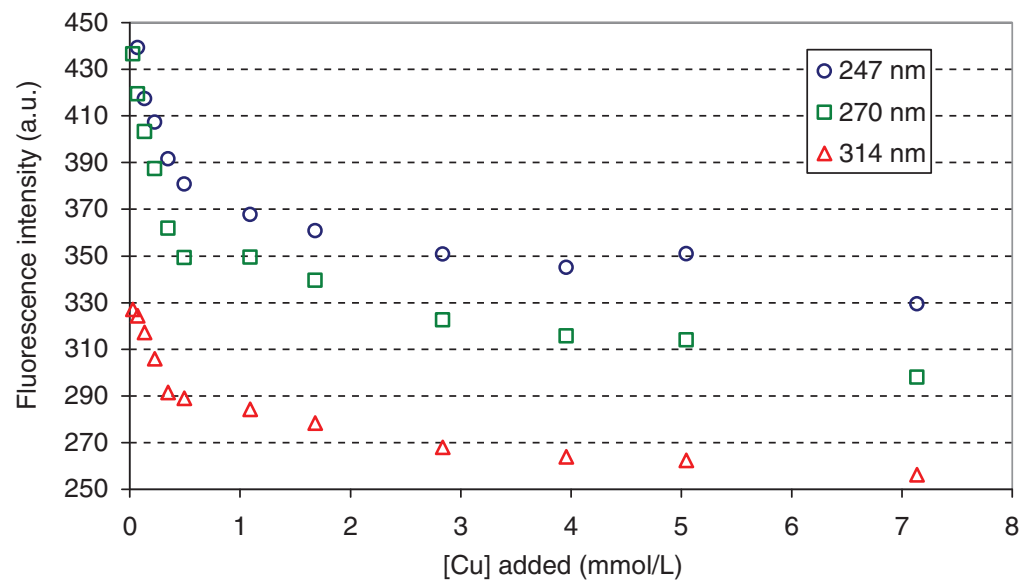

Figure 8. Fluorescence quenching data obtained on the various fluorophores of OM in sample D65 $\left(25^{\circ} \mathrm{C}\right)$ (a.u.: arbitrary unit).

domestic wastes are responsible for the anthropogenic origin of this OM for D01 and D65 samples.

The ligand L6 of the SLN sample (D01) was outstanding (Table 3): the pKa was much more basic (10.99) compared to the other samples and the L6 ligand's concentration was surprisingly very high as well $\left(0.636 \mathrm{mmol} \mathrm{L}^{-1}\right)$. The typical signature of SLN sample indicates the presence of an OM probably richer in phenolic groups, than in the other samples of anthropogenic origins.

Generally, from the potentiometric data, we can notice that the phenolic groups (ligand L6) were dominating in the marine type OM samples, whereas the most acidic and the most basic ligands were both highly concentrated in the anthropogenic OM samples.

\subsubsection{Fluorescence quenching modelling}

The fluorescence quenching experiments are modelled in order to determine the stability constant (K) and complexing capacity (CC) of the $\mathrm{OM}$ in regard to metal ions. The quenching fluorescence experiment can be performed on any fluorophore signal, affected by metal complexation. As shown in Figure 8 (D65 sample), the signal of peaks A, C/M and protein-like are all quenched upon metal addition for all the samples. We chose to monitor the quenching of the A peak of each retentate $1 \mathrm{kDa}$ sample in these experiments for the modelling since the intensity of this peak was the most intense. This is expected since fulvic acid-type molecules are more soluble than humic acid-like molecules under acidic and neutral $\mathrm{pH}$. Figure 9 is an illustration of the fluorescence signal intensity quenched upon copper addition on the peak A (sample D65). The excitation wavelength was set to $245 \mathrm{~nm}$ while the emission wavelength was scanned in the range 260 to $470 \mathrm{~nm}$ according to the maximum intensity obtained (Table 2). The fluorophore compounds are mainly of aromatic nature and loose their ability to fluoresce after metal complexation. Neighbour complexing groups can also affect these fluorescence properties. The experimental data obtained are modelled according to the Ryan and Weber model [31], as shown for example in Figure 10, for sample D65 (R1kDa). Figure 10 shows the 




Figure 9. Fluorescence quenching raw data obtained on the peak A of D65 sample upon $\mathrm{Cu}$ addition $\left(25^{\circ} \mathrm{C}\right)$.

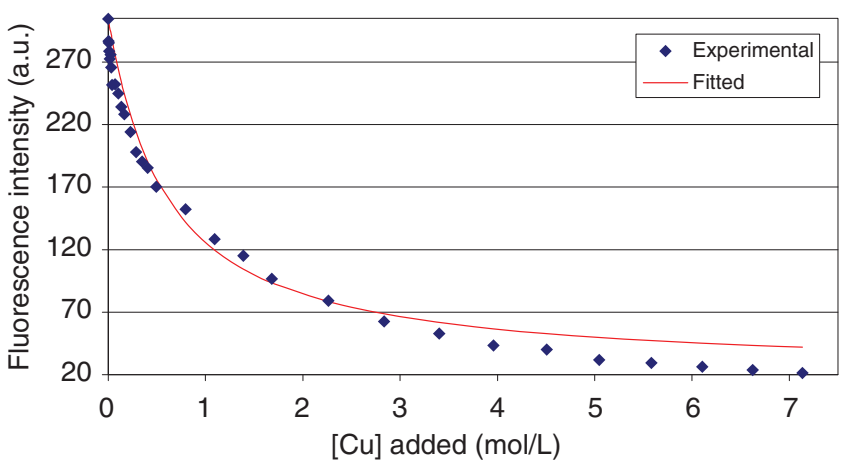

Figure 10. Fluorescence quenching curve (experimental and fitted data) upon $\mathrm{Cu}$ logarithmic addition (D65 sample, peak $\mathrm{A}, \mathrm{R} 1 \mathrm{kD}, 25^{\circ} \mathrm{C}$ ) (a.u.: arbitrary unit).

experimental and fitted data for the quenching of fluorescences obtained on D65 (garbage dump, peak A of the retentate R1kDa) sample upon logarithmic addition of copper. Only D65 results were shown for the sake of simplicity but all the samples were submitted to the same procedure. We can see in Figure 10 that the exponential decrease of the intensity at lowest copper concentrations is well fitted, but, due to theoretical model, the fit is not perfect. Indeed, $\mathrm{OM}$ is considered as a complexing ligand as a whole, without discriminating the various fluorescent fluorophores. However, the modelling allowed one to compare the samples to each other.

Table 4 gives the modelling results of the complexing capacity $\left(\mathrm{CC}\right.$ in $\left.\mathrm{mol} \mathrm{L}^{-1}\right)$ and complexing constant $(\log \mathrm{K})$ of the $\mathrm{OM}-\mathrm{Cu}$ complexes obtained by fluorescence quenching experiments. The reference sample (M06) result indicated that the pure marine OM-Cu complexes were weaker than the ones formed with anthropogenic OM. Indeed, the dilution effect from residence and from SLN resulted in a decrease of the mean stability constant, due to a pure marine OM incorporation in the complexes. At the same time, the complexing capacity decreased upon dilution, as pure marine OM had a lower CC than the anthropogenic OM. These results are in accordance with the ones obtained from the potentiometric modelling. These data are not favourable to environmental safety since 
Table 4. Modelling results of the fluorescence quenching data ( $\mathrm{Cu}$ complexes).

\begin{tabular}{llcc}
\hline Sampling Site & Log K & CC $\left(\mathrm{mol} \mathrm{L}^{-1}\right)^{\mathrm{b}}$ \\
\hline M06 & Reference & 3.30 & $6.19 \times 10^{-5}$ \\
N04 & Residence & 3.39 & $9.04 \times 10^{-5}$ \\
N20 & Residence further & 3.25 & $4.01 \times 10^{-5}$ \\
D65 & Garbage Dump & 3.25 & $7.64 \times 10^{-5}$ \\
D47 & Garbage dump further & 3.35 & $2.04 \times 10^{-4}$ \\
D01 & SLN & 3.28 & $1.33 \times 10^{-4}$ \\
D32 & SLN further & 3.10 & $5.23 \times 10^{-5}$ \\
\hline
\end{tabular}

Note: ${ }^{a}$ stability constant, ${ }^{b}$ complexing capacity.

Table 5. Modelling results of the polarographic data.

\begin{tabular}{lccc}
\hline & {$[\mathrm{Pb}] \mathrm{mol} \mathrm{L}^{-1}( \pm 5 \%)^{\mathrm{a}}$} & $\log \mathrm{K}^{\mathrm{b}}$ & $\mathrm{CC}\left(\mathrm{mol} \mathrm{L}^{-1}\right)^{\mathrm{c}}$ \\
\hline M06 & $1.07 \times 10^{-7}$ & 10.24 & $8.07 \times 10^{-8}$ \\
N04 & $8.32 \times 10^{-6}$ & 11.74 & $8.27 \times 10^{-6}$ \\
N20 & $5.75 \times 10^{-6}$ & 11.53 & $5.78 \times 10^{-6}$ \\
D65 & $3.09 \times 10^{-6}$ & 11.38 & $3.09 \times 10^{-6}$ \\
D47 & $2.29 \times 10^{-6}$ & 10.34 & $2.28 \times 10^{-6}$ \\
D01 & $5.75 \times 10^{-6}$ & 11.75 & $8.89 \times 10^{-6}$ \\
D32 & $1.95 \times 10^{-5}$ & 11.58 & $2.28 \times 10^{-5}$ \\
\hline
\end{tabular}

Note: ${ }^{\mathrm{a}}$ labile $\mathrm{Pb}$ concentration, ${ }^{\mathrm{b}}$ stability constant, ${ }^{\mathrm{c}}$ complexing capacity.

anthropogenic $\mathrm{OM}$ would be able to transport metal ions farther, and are more strongly bound to metals, making them less subject to competition for metal binding sites.

\subsubsection{Voltammetric modelling}

According to polarographic data (Table 5), the reference (M06) exhibited the smallest complexing capacity in accordance with the potentiometric titrations and fluorescence data that showed that the site density of M06 acido-basic ligands were the smallest. Furthermore, the reference sample (M06) had the lowest complexing constant, indicating weaker OM-metal complexes. The same result was pointed out from the fluorescence quenching results regarding $\mathrm{Cu}$.

Moreover, polarographic results (Table 5) showed that the dilution effect from N04 (residence) to N20 induced a decrease of the CC and the $\log \mathrm{K}$ parameters towards values closer to the reference ones (M06), which is in accordance with the results obtained with fluorescence data and potentiometric data: the dilution occurs with pure marine water. However, the $\mathrm{pKa}$ and site density of ligand $\mathrm{L} 1$ obtained from potentiometric data (Table 3) for SLN farther (D47), that was considered as well as marine sample from fluorescence experiments seem to indicate that anthropogenic OM was also present. The total site density was much lower for the pure marine OM (reference (M06), $5.5 \times 10^{-1} \mathrm{mmol} \mathrm{L}^{-1}$ ), compared to the anthropogenic OM (SLN (D01), garbage dump (D65), residence (N04)). The dilution effect from the garbage dump (from D65 to D47) did not seem to come from pure marine water, since the site density of D47 increased 
compared to D65 (from $6.7 \times 10^{-1}$ to $9.1 \times 10^{-1} \mathrm{mmol} \mathrm{L}^{-1}$ ). It seems that the dilution effect came from another type of OM, which could be from the Dumbea River. We can notice as well, from polarographic results, the significant drop in the complexing constant $\log \mathrm{K}$ value after dilution for the D47 sample (1.04 unit drop), which, as was pointed out with potentiometric titrations, would confirm a different origin of the marine $\mathrm{OM}$ in the dilution water: the Dumbea River. This is confirmed by fluorescence data: after dilution, the $\log \mathrm{K}$ of the OM-complexes increased, as the $\mathrm{CC}$ did. The source of OM from the Dumbea River could explain this result, as a source of better complexing OM. Another hypothesis is that some binding sites of the OM were not available for complexation since other metal ions were already included in complexes with the OM. The competition with other metal ions could result in a decrease of the OM CC and the $\log \mathrm{K}$. This is probably the reason why the $\log \mathrm{K}$ of the complexes for the most polluted zones D65 or D01 are lower than the reference.

\subsubsection{Metal and DOC correlation}

Figure 11 shows the correlations between the carbon concentration, complexing capacity (for copper from fluorescence modelling data), and the labile concentrations in $\mathrm{Cu}, \mathrm{Pb}$ and $\mathrm{Cd}$. We can see (Figure 11a) that the more the sample was concentrated in carbon and higher was the complexing capacity, which confirms that $\mathrm{Cu}$ was bound to $\mathrm{OM}$ preferentially during its transport in the dissolved phase. For the D47 sample (garbage dump farther), the trend was different: less carbon were present but the CC was higher. This result seems to show that Dumbea River brought OM poorer in carbon but higher in site density. We saw previously that this $\mathrm{OM}$ was less strongly bound to $\mathrm{Pb}$ but it appears here that it had a greater affinity for $\mathrm{Cu}$. The stability constant found for our $\mathrm{Pb}-$ complexes are in the same order of magnitude as the ones found by Vasquez [49] by polarographic analysis: 9.9 in average.

Figure $11 \mathrm{~b}$ also shows that competition of $\mathrm{Cu}$ resulted in the drop of $\mathrm{CC}$ values obtained. Indeed, D65 sample which presented a particularly high quantity of $\mathrm{Cu}$, had a much lower $\mathrm{CC}$ value compared to $\mathrm{D} 47 . \mathrm{Pb}$ and $\mathrm{Cd}$ did not seem to be involved in competition effect, but only $\mathrm{Cu}$ did. For the other samples, we can see clearly the dilutions effects as discussed previously, as the labile $\mathrm{Cu}$ levels were in the same range of magnitude for all the samples (allowing a more accurate comparison).

\section{Conclusion}

The presence and quantification of specific metals were evidenced according to the various activities taking place nearby the shore. Dilution effects from the coastline were as well evaluated and seemed to be efficient within a few kilometres' distance. SLN, garbage dump and residence samples were found responsible for metal inputs in the lagoon, but the concentrations remained quite moderate. The metals studied seemed, however, to have better affinity for the solid phase of $\mathrm{OM}$, in particular $\mathrm{Zn}$ and $\mathrm{Pb}$, which could result in their accumulation in sediments.

The molecular fluorescence, potentiometry and differential pulse anodic stripping voltametry (DPASV) were used as tools to discriminate the properties of the OM originating from various sources. The modelling data helped predicting the fate of metal ions in the dissolved phase. The various experiments were complementary since they determined acido-basic properties, fluorescence spectra data, complexing capacity and 

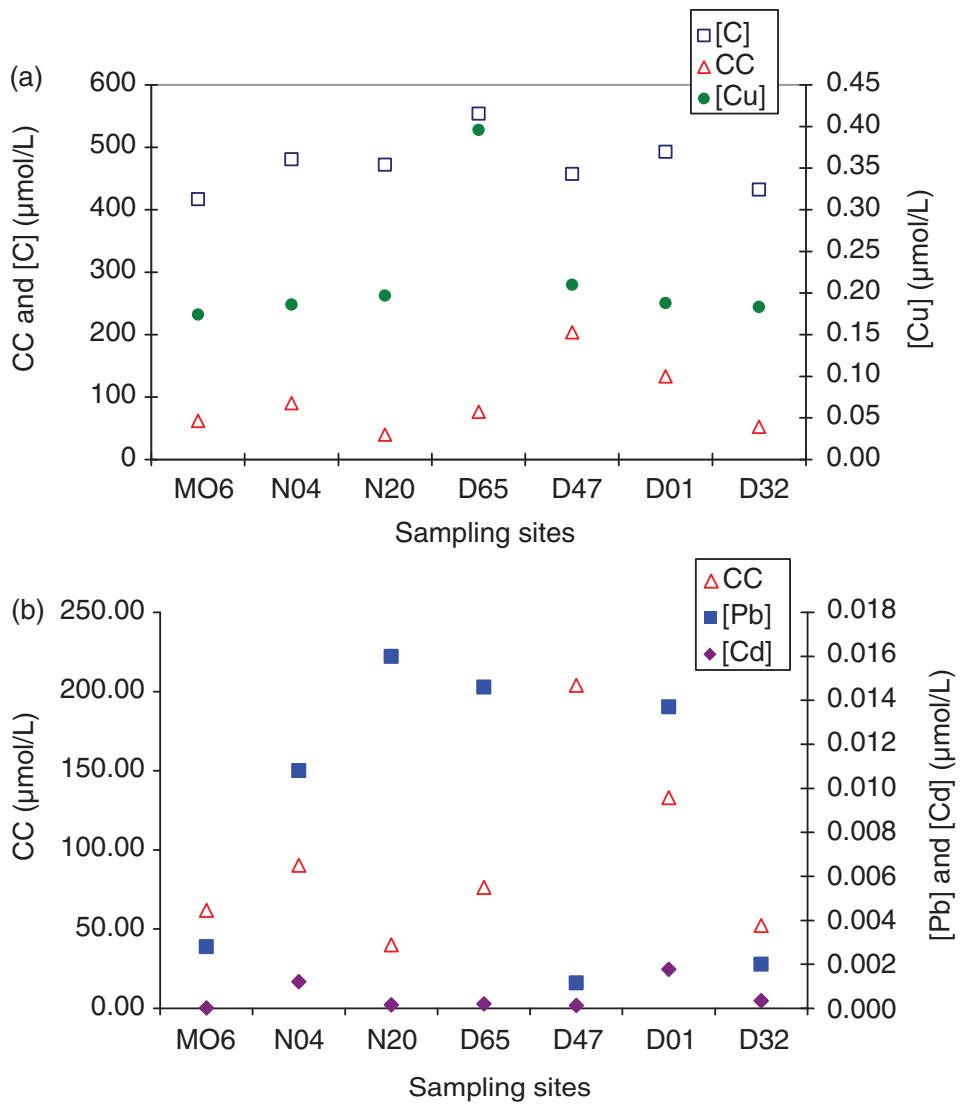

Figure 11. Correlation between labile metal content (measured from polarographic data), carbon concentration and complexing capacity of the $\mathrm{OM}$ (in $\left.\mu \mathrm{mol} \mathrm{L} \mathrm{L}^{-1}\right)$.

stability constants, for $\mathrm{Cu}$ and $\mathrm{Pb}$. The results showed that we had two main types of OM: marine and anthropogenic types. However, among the anthropogenic types, the OM exhibited very different behaviour and properties, according to the industrial or urban activities. Some samples were clearly diluted with marine OM and presented both features. Generally, we found that, marine OM presented less affinity for metals and was lower in site density compared to the anthropogenic OM. As an environmental impact, this would result in a metal transport facilitated by the anthropogenic OM, farther from the shore.

For $\mathrm{Pb}$ and $\mathrm{Cu}$, anthropogenic $\mathrm{OM}$ had higher $\mathrm{CC}$ and $\log \mathrm{K}$ values than marine $\mathrm{OM}$, which means that it binds more metal and stronger than the marine OM. However, competition effect from other metal ions present in the most contaminated samples seemed to decrease the stability constant found for anthropogenic OM-metal complexes. In the polarographic data obtained, the competition effect was not seen because $\mathrm{Pb}$ was forming stronger complexes with humic like molecules than $\mathrm{Cu}$ or $\mathrm{Zn}$, for example [52]. Further experiments after a Chelex resin treatment to remove the metals already present in the samples could be attempted as future work to give the stability constants and complexing capacity without any interfering metal ions. 
Other metal ions would have been interesting to study, such as chromium, present in water or soils [53], and which is associated with Ni mining activities. Furthermore, to complement the study, sediment sampling could be done to evaluate the extent of metal accumulation.

Modelling of potentiometric titrations in the presence of $\mathrm{Cu}$ and $\mathrm{Pb}$, alone and in competition are ongoing in order to complete the information given by the other techniques especially. Furthermore, a multi-ligand modelling with PROSECE software for the DPASV data will be held to give more details about the nature of OM that are mainly responsible for metal binding. Indeed, the model 1:1 allowed a comparative study but is simplistic, considering the structural complexity of the OM.

Finally, spectroscopic analysis, such as IR, NMR ${ }^{1} \mathrm{H}$ and ${ }^{13} \mathrm{C}$ would allow one to confirm and complete the data obtained; in particular, it would help in giving a spectral signature of the various types of $\mathrm{OM}$ detected in this study.

\section{Acknowledgements}

The authors would like to thank the national framework PNEC (French National Programme on Coastal Environment) for the financial support of this project, and the IRD research centre in Noumea (New Caledonia) for their logistic and scientific support.

\section{References}

[1] M.J. Kennish, in Ecology of Estuaries: Anthropogenic Effects, edited by M.J. Kennish (CRC Press, Boca Raton, 1992).

[2] P. Labrosse, R. Fichez, R. Farman, and T. Adams, in Seas at the Millennium: An Environmental Evaluation, edited by C.R.C. Sheppard (Pergamon Press, Amsterdam, 2000), pp. 723-736.

[3] S. Bujan, C. Grenz, R. Fichez, P. Douillet, and C.R. Acad., Sci. Paris, Life Sc. Ecol. 323, 225 (2000).

[4] N. Mary and P. Marmonier, Hydrobiologia. 418, 199 (2000).

[5] J. Launay, La sédimentation en baie de Dumbéa (Côte ouest - Nouvelle-Caledonie) (Cahiers Orstom, série Géologique IV (1), 1972), pp. 25-51.

[6] F. Monniot, R. Martoj, and C. Monniot, Ann. Inst. Océanogr. 70, 205 (1994).

[7] P. Ambatsian, F. Fernex, M. Bernat, C. Parron, and J. Lecolle, J. Geochem. Explor. 59, 59 (1997).

[8] P. Bustamante, C. Garrigue, L. Breau, F. Caurant, W. Dabin, J. Greaves, and R. Dodemont, Environ. Pollut. 124, 263 (2003).

[9] P. Bustamante, S. Grigioni, R. Boucher-Rodoni, F. Caurant, and P. Miramand, Mar. Pollut. Bull. 40, 688 (2000).

[10] S. Ouillon, P. Douillet, and S. Andréfouêt, Coral Reefs. 23, 109 (2004).

[11] M. Gnassia-Barelli and M. Romeo, Some aspects of lead ecotoxicology in the marine environment. Aquatic Toxicol. 26 (3-4), 163 (1999).

[12] Directive 2002/95/EC of the European parliament and of the council of 27 January 2003 on the restriction of the use of certain hazardous substances in electrical and electronic equipment.

[13] G. Sposito, in The Chemistry of Soils, edited by Oxford University Press (New York, 1989).

[14] R.S. Anderson, in Pathobiology of Marine and Estuarine Organisms, edited by J.A. Couch and J.W. Fournie (CRC Press, Boca Raton, 1993), pp. 483-510.

[15] G.W. Bryan, Journal Proceedings of the Royal Society of London. Series B, Biological Sciences (1934-1990). 177, 389 (1971).

[16] A.O. Ogunfowokan and O.A. Fakankun, Int. J. Environ. Studies. 54, 145 (1998). 
[17] E. Merian, in Metals and their Compounds in the Environment, Occurrence, Analysis and Biological Relevance, edited by VCH (Weinheim, 1991).

[18] N. Kobayashi and H. Okamura, Chemosphere. 55, 1403 (2004).

[19] A.M. Farag, D. Skaar, D.A. Nimick, E. MacConnell, and C. Hogstrand, trans. Am. Fish Soc. 132, 450 (2003).

[20] A.H. Weatherley, P.S. Lake, and P.L. Stahal, in Zinc in the Environment and Ecological Cycling, edited by J.O. Nriagu (John Wiley, New York, 1988).

[21] O.S. Fatoki, N. Lujiza, and A.O. Ogunfowokan, Water South Africa. 28, 183 (2002).

[22] J. Buffle, J. Electroanal. Chem. 125, 273 (1981).

[23] L. Hédouin, P. Bustamante, C. Churlaud, O. Pringault, R. Fichez, and M. Warnau, Ecotox. Environ. Safe. 72, 372 (2009).

[24] D. Vignati, Terre et Environnement. 44, 272 (2004).

[25] K. Mopper, Z. Feng, S.B. Bentjen, and R.F. Chen, Marine Chem. 55, 53 (1996).

[26] C. Garnier, S. Mounier, and J.Y. Benaïm, Environ. Technol. 25(5), 589 (2004).

[27] J. Cao, K.C. Lam, R.W. Dawson, W.X. Liu, and S. Tao, Chemosphere. 54, 507 (2004).

[28] C. Garnier, I. Pizeta, S. Mounier, J.Y. Benaïm, and M. Branica, Anal. Chim. Acta. 505, 263 (2004).

[29] F.M.M. Morel, Principles of Aquatic Chemistry (John Wiley \& Sons Interscience, New York, 1983).

[30] Y.K Chau and K. Lum-Shue-Chan, Water Res. 8, 383 (1974).

[31] D.K. Ryan and J.H. Weber, Anal. Chem. 54, 986 (1982).

[32] H.M. Fernandes, E. Dausacker Bidone, L.H. Sadler Veiga, and S.R. Patchineelam, Environ. Pollut. 85, 259 (1994).

[33] M. C. Garrido Pérez, D. Sales Márquez, E. Nebot Sanz, and F. López-Aguayo, Bol. Inst. Esp. Oceanogr. 15 (1-4), 523 (1999).

[34] C. Migon, S. Ouillon, X. Mari, and E. Nicolas, Estuar. Coast. Shelfs. 74, 756 (2007).

[35] G. Rand, in Fundamentals in Aquatic Toxicology. Effects, Environmental Fate and Risk Assessment, edited by G.M. Rand (Taylor \& Francis, Washington D.C., 1995), p. 1125 .

[36] A.G. Dalto, A. Grémare, A. Dinet, and D. Fichet, Estuarine, Coast. Shelf Sc. 67, 629 (2006).

[37] M. Metian, L. Hédouin, C. Barbo, J.-L. Teyssié, S.W. Fowler, F. Goudard, P. Bustamante, J.-P. Durand, J. Piéri, and M. Warnau, B. Environ. Contam. Tox. 75, 89 (2005).

[38] P. Douillet, S. Ouillon, and E. Cordier, Coral Reefs. 20, 361 (2001).

[39] M.F. Buchman, NOAA Screening Quick Reference Tables, NOAA HAZMAT Report 99-1, Coastal Protection and Restoration Division (National Oceanic and Atmospheric Administration, Seattle, W.A., 1999), p. 12.

[40] E.R. Long, D.D. MacDonald, S.L. Smith, and F.D. Calder, Environ. Manage. 19, 81 (1995).

[41] R.N. Jordan, D.R. Yonge, and W.E. Hathhorn, J. Contam. Hydrol. 29, 59 (1997).

[42] B.C. MacDonald, S.J. Lvin, and H. Patterson, Anal. Chim. Acta. 338, 155 (1997).

[43] L.E. Band, C.L. Tague, P. Groffman, and K. Belt, Hydrol. Process. 15, 2013 (2001).

[44] E. Tipping, A.F.H. Marker, C. Butterwick, G.D. Collett, and P.A. Cranwell, Sc. Total Environ. 194, 345 (1997).

[45] J. Clavier, P. Chardy, and C. Chevillon, Estuar. Coast. Shelf Sci. 40, 281 (1995).

[46] J.M. Fox, P.S. Hill, T.G. Milligan, and A. Boldrin, Marine Geol. 203, 95 (2004).

[47] A.L. Wilson, Trace Metals in Waters, Philosophical Transactions of the Royal Society of London, Series B, Biological Sciences, Environmental Geochemistry and Health 288, 25 (1979).

[48] C.V. Miller, G.D. Foster, and B.F. Majedi, Appl. Geochem. 18, 483 (2003).

[49] F.G. Vazquez, V.K. Sharma, V.H. Alexander, and C.A. Frausto, Environ. Health Persp. Supplement 1: Fate, Transport, and Interactions of Metals, 103, 33 (1995). 
[50] P.G. Coble, Mar. Chem. 51, 324 (1996).

[51] M.M.D. Sierra, M. Giovanela, E. Parlanti, and E.J. Soriano-Sierra, Chemosphere. 58, 715 (2005).

[52] J. Buffle, Complexation Reactions in Aquatic Systems, An Analytical Approach (Ellis Horwood, Chichester, UK, 1988), p. 692.

[53] M. Korolczuk, Anal. Chim. Acta. 414, 165 (2000). 